WORKING PAPER · NO. 2020-167

\title{
Has Persistence Persisted in Private Equity? Evidence from Buyout and Venture Capital Funds
}

Robert S. Harris, Tim Jenkinson, Steven N. Kaplan, and Ruediger Stucke

NOVEMBER 2020 


\title{
HAS PERSISTENCE PERSISTED IN PRIVATE EQUITY? EVIDENCE FROM BUYOUT AND VENTURE CAPITAL FUNDS
}

\author{
Robert S. Harris \\ Tim Jenkinson \\ Steven N. Kaplan \\ Ruediger Stucke
}

November 2020

This version updates and greatly extends an earlier version written in 2014. The research has been supported by the UAI Foundation and the Center for Research in Security Prices. Rui Cui and Wendy Hu provided excellent research assistance. We thank Burgiss for supplying data. Kaplan has consulted to venture capital and buyout general partners and limited partners. Stucke is employed by a private equity fund.

(C) 2020 by Robert S. Harris, Tim Jenkinson, Steven N. Kaplan, and Ruediger Stucke. All rights reserved. Short sections of text, not to exceed two paragraphs, may be quoted without explicit permission provided that full credit, including (C) notice, is given to the source. 
Has Persistence Persisted in Private Equity? Evidence from Buyout and Venture Capital Funds Robert S. Harris, Tim Jenkinson, Steven N. Kaplan, and Ruediger Stucke November 2020

JEL No. G11,G24

\begin{abstract}
We present new evidence on the persistence of U.S. private equity (buyout and venture capital) funds using cash-flow data sourced from Burgiss's large sample of institutional investors. Previous research, studying largely pre-2000 data, finds strong persistence for both buyout and venture capital (VC) firms. Using ex post or most recent fund performance (as of June2019), we confirm the previous findings on persistence overall as well as for pre-2001 and post-2000 funds. However, when we look at the information an investor would actually have - previous fund performance at the time of fundraising rather than final performance - we find little or no evidence of persistence for buyouts, both overall and post-2000. For post-2000 buyouts, the conventional wisdom to invest in previously top quartile funds does not hold. Using previous fund PME at fundraising, we find modest persistence, but it is driven by bottom, not top quartile performance. On the other hand, persistence for $\mathrm{VC}$ funds persists even when using information available at the time of fundraising. Therefore, the conventional wisdom of investors holds for VC.
\end{abstract}

Robert S. Harris

University of Virginia

Darden School of Business

100 Darden Boulevard

Charlottesville, VA 22903

HarrisR@darden.virginia.edu

Tim Jenkinson

University of Oxford

Said Business School

Park End Street

Oxford OX1 1HP

UK

tim.jenkinson@sbs.ox.ac.uk
Steven N. Kaplan

Booth School of Business

The University of Chicago

5807 South Woodlawn Avenue

Chicago, IL 60637

and NBER

steven.kaplan@chicagobooth.edu

Ruediger Stucke

Warburg Pincus LLC

450 Lexington Ave

New York, NY 10017

ruediger.stucke@warburgpincus.com 


\section{Introduction}

It has long been conventional wisdom for investors in private equity to choose funds run by managers who have performed well in the past, particularly, so-called top-quartile funds, while avoiding first-time funds. ${ }^{1}$ This conventional wisdom is based on the belief that performance in private equity persists across successive funds - typically organized as limited partnerships - with the same manager (the general partner or GP). Previous academic research, studying largely pre-2000 data for the U.S., has been consistent with this conventional wisdom. For example, Kaplan and Schoar (2005) find evidence of persistence in venture capital (VC) and buyout funds raised in the 1980s and 1990s. Robinson and Sensoy (2016) obtain similar results for a sample of buyout funds, again raised largely in the 1980s and 1990s. Chung (2012) studies buyout and VC funds raised through 2000 and finds somewhat less persistence than the other papers.

While previous work finds persistence, there are three questions about its existence. First, Kaplan and Schoar (2005) rely on Venture Economics data that Stucke (2011) and Harris, Jenkinson and Kaplan (2014), HJK, subsequently show to be flawed. Robinson and Sensoy (2016) rely on fund investments of just one investor. Chung (2012) does not have access to fundlevel cash flows. Most of the existing research relates to funds formed before 2000, and so misses the large increase in allocations to buyout funds since 2000 and the collapse in allocations to VC after the dot-com bubble burst. Second, from the perspective of fund investors (the limited partners, or LPs), Sensoy, Wang and Weisbach (2014) find that the ability of certain types of investors to achieve higher performance, as originally found by Lerner, Schoar and Wongsunwai (2007), has disappeared in recent years. This may reflect a reduction in performance persistence that GPs achieve, thus decreasing the value of long-established relationships between LPs and particular GPs. Third, and perhaps most importantly, existing papers study the relation between the final or most recent performance of different funds managed by the same GP. Such comparison typically rely on information that is not generally available at the time that an investor decides to commit to / invest in a new fund. This is particularly the case when comparing the performance of fund $\mathrm{N}+1$ with fund $\mathrm{N}$ : the commitment to invest in fund $\mathrm{N}+1$ will occur midway through the life of fund $\mathrm{N}$, at which point only interim performance measures are available

\footnotetext{
${ }^{1}$ For example, see Swensen (2000) and Mulcahy et al. (2012)
} 
based, to some extent, on the estimated net asset values of the remaining unrealized portfolio companies of fund $\mathrm{N}$.

In this paper, we present new and more recent evidence on the persistence of U.S. buyout and VC funds using the research-quality dataset from Burgiss first used in HJK (2014). A key attribute of the Burgiss data is that they are derived entirely from LPs for whom Burgiss' systems provide record-keeping and performance monitoring services. This feature results in detailed, verified and cross-checked investment histories for thousands of private equity funds (of all types) derived from the holdings of institutional investors. These data have now been sequenced by GP and fund type. That is, in cases where GPs establish different fund strategies - such as funds focused on buyouts and other funds focusing on a specific sector, such as technology - we sequence these funds separately. Using detailed cash-flow data at the fund level, we study the persistence of U.S. buyout and VC performance of the same GPs across over 2,200 funds. All the returns we study in this paper are net of all management fees and profit shares ('carried interest').

Unlike previous studies, we pay careful attention to the performance of a GP's previous funds at the time the GP is raising the next fund. In other words, in addition to considering fund persistence based on ex post (i.e., final or most recently available at the time of our study) fund performance, we also consider persistence based on performance information available to LPs at the time of fundraising when the LP must make its investment decision.

Our main results are as follows. First, using final or most recently available fund performance, as of June 2019, we confirm the previous findings on persistence. We group funds into performance quartiles at the end of fund life and compute the transition matrix for the current fund performance. For our overall sample, as well as for both pre-2001 and post-2000 funds, fund performance is persistent. The conventional wisdom would appear to hold.

Second, however, using performance information available at the time of fundraising, the results differ. For buyout funds with post-2000 vintages, performance persistence based on fund quartiles disappears. When funds are sorted by the performance quartile of the GP's previous fund at the time of fundraising, performance of the current buyout fund is statistically indistinguishable regardless of quartile. First-time funds perform at least as well as any of the groups based on prior fund quartile rankings. Moreover, returns for buyout funds in all previous fund quartiles as well as first-time funds exceed those of public markets as measured by the S\&P 500 . 
For VC funds, in contrast, performance persistence still exists, when measured by the final (or most recent) performance of funds: top quartiles tend to repeat such performance nearly $45 \%$ of the time. In contrast to buyouts, when using information available at the time of fundraising, performance persistence exists but has become weaker for funds formed after 2000. General partners of both buyout and VC firms raise next funds when the performance of their previous funds is strong. ${ }^{2}$

Our results are consistent with those in Harris et al. (2018) who find that VC funds of funds earn their fees while buyout funds of funds do not, suggesting that VC funds of funds can identify better performing VC funds ex ante, while buyout funds of funds cannot. The inability to choose buyout funds based on past performance post-2000 is also consistent with Sensoy et al. (2014) who find that post-1998, endowments no longer outperform in choosing private equity funds.

Third, we augment our quartile-based analyses with regression analyses, based on public market equivalent (PME) returns (Kaplan and Schoar (2005)). We regress current fund PMEs against the PMEs of previous funds at fundraising. For post-2000 VC funds, the regressions, like those for quartiles, find persistence.

For post-2000 buyout funds, the PME regressions, unlike those using quartiles, indicate there is only modest persistence. This also suggests that for buyouts, previous fund PME is a better measure of subsequent performance than previous fund quartile. The persistence, however, is driven by the persistence of funds in the bottom quartile of the previous PME distribution. There is no statistical difference in performance among previous funds in the top three quartiles of previous PME performance. The regressions for buyouts also find no significant impact of increased fund sizes on performance.

Finally, in order to properly analyze performance persistence, we address the fact that successful GPs have increasingly raised non-core funds. For example, Bain Capital has Bain Ventures while Sequoia Capital also has Sequoia Growth. We measure performance persistence within each fund family or style (so would sequence Sequoia Growth separately from Sequoia Capital). Separating these track records is important for our analysis, and has not previously been possible with the Burgiss data. In our regression analysis, we find that the 'core' fund styles of

\footnotetext{
${ }^{2}$ All of the results are qualitatively similar if we use a 2003 cutoff instead of a 2000 cutoff.
} 
buyout GPs perform better than 'secondary' style funds that are launched later. We find no such reduction in performance in the case of $\mathrm{VC}$ funds.

The paper proceeds as follows. In section 2, we discuss the data used. In section 3, we present and discuss our persistence results based on quartile transitions. In section 4, we present performance persistence regressions, and analyze the impact of fund size increases and non-core funds. In section 5, we conclude and summarize the implications of our results.

\section{Data}

In this paper, we use performance data for U.S. buyout and VC funds from Burgiss, with valuations and cash-flows up to the end of June 2019. The Burgiss dataset "is sourced exclusively from LPs and includes their complete transactional and valuation history between themselves and their primary fund investments. The flows are rescaled to be representative of the full fund." In other words, the Burgiss data include all funds and cash flows from the LPs that provide the data. Because the data are net of all fees and carried interest paid to the GP, our performance measures represent the net returns to the LPs who invest in the funds. Over 1,000 LPs now use the Burgiss platform and comprise a wide array of investors including public and private pension plans, endowments and foundations, family offices, and others.

The underlying cash flow data of the funds are likely to be highly accurate because LPs use Burgiss' systems for record keeping and fund investment monitoring. This "check book" data - recording the exact cash outflows made by the LPs to the GPs as well as the distributions from the GPs back to the LPs - has a number of advantages for research purposes. The fact that the data are sourced from the back-office systems used by the LPs for reporting and fund accounting, and are cross-checked across investors in the same fund, results in levels of data integrity and completeness that cannot be achieved by surveys, voluntary reporting, or (largely) involuntary reporting using Freedom of Information (FOIA) requests (the main method employed by Preqin). Furthermore, when data are sourced from GPs it is possible for a GP to strategically stop reporting, or to only report on their funds selectively. The Burgiss data also are up to date given the need for quarterly reporting by most investors - and so there are no problems with a lack of updating as there can be with other commercial databases. In other words, for a given LP, 
there is unlikely to be any selection bias. This is an advantage over other commercial sources whose data rely on voluntary and FOIA disclosures by GPs and LPs.

The potential bias in the Burgiss data - which it shares with the other commercial sources - is how representative the LPs (and resulting GPs) are. For example, it is possible that the LPs in the Burgiss sample have had better than average experience with private equity, which is why they use Burgiss and allow Burgiss to aggregate their results. However, the results in HJK (2014, 2016) suggest that this bias is not present. HJK (2014) provide a more detailed discussion of the Burgiss data, its advantages, and how it compares to other samples. ${ }^{3}$

Burgiss identifies the GP and the type of fund (or funds) offered by the GP. From this, we produce a sequence number for each fund in a fund strategy. Some GPs only have one set of funds that stick to the same investment focus; we call this a fund strategy. However, if the GP has raised more than one type of fund - for example VC funds and then a sector-focused sequence of funds - this allows us to track the performance persistence of each fund strategy separately. It also allows us to distinguish between the GP's initial or main funds and subsequent fund families. We do this because the characteristics and the partners of the different types of funds can vary. We also eliminate annex funds and side funds. Annex funds are funds that extend an existing fund. Side funds are invested side-by-side with the main fund and have the same performance.

Our analyses compare performance for funds in a particular fundraising (vintage) year. Burgiss classifies a vintage year as the year in which a fund first draws capital from its LPs. We report performance for vintages from 1984 through 2014. Relatively few funds have available data pre-1984. We do not include vintages after 2014 because we want to give funds sufficient aging to deliver meaningful performance - in our case, at least five years.

Table 1 provides summary information on the 2,222 funds in our sample, by vintage year. In order not to be able to identify individual funds, we do not report results for vintage years with fewer than five funds. Panel A describes the 893 buyout funds, which overall represent committed capital of over \$1 trillion. Kaplan and Schoar's (2005) sample studied 169 buyout funds. For 484 of these funds, we have the performance of the prior fund in the sequence. For instance, if we have funds 1, 2, 4 and 5 from a given fund sequence, we have 2 adjacent pairs that

\footnotetext{
${ }^{3}$ HJK (2014 and 2016) use cash-flow data up to the end of March 2011 and June 2014. This paper uses cash-flows up to June 2019, and so provides an update to the performance analysis. Additional funds have been added to the Burgiss data set, and so the sample size in this paper is somewhat larger.
} 
we can analyze. The difference comprises (a) 204 first-time funds and (b) 205 funds (which were not first-time funds) for which Burgiss lacks prior fund performance information. The latter reflects the fact that our data are derived entirely from LPs - who do not necessarily invest in every fund offered by a GP. This inevitably leads to gaps in the fund sequences.

Panel B focuses on the 1,329 VC funds in the sample, which raised over $\$ 300$ billion in total. Kaplan and Schoar's sample studied 577 VC funds. Prior fund information is available for 726 of our sample of funds. We also have information for 287 first-time funds and 316 non-firsttime funds for which Burgiss lacks prior fund performance.

Table 1 also reports the unrealized portion of the funds remaining, as of June 2019, as a percentage of the total value (unrealized plus already realized) for an LP in the fund. For buyout funds, vintage years before 2007 are, on average, at least 90\% realized. Only the 2013 and 2014 vintage years are less than 50\% realized. For VC funds, vintage years before 2007 are, on average, at least $70 \%$ realized. Vintages from 2011 to 2014 are less than $30 \%$ realized.

While we would prefer the recent funds to be more fully realized, the unrealized values should approximate true market values. Since the end of 2009, ASC 820 of the Financial Accounting Standards Board (FASB) has required private equity firms to value their assets at fair value every quarter, rather than permitting them to value the assets at cost until an explicit valuation change. This has likely had the practical effect of making estimated unrealized values closer to true market values than in the past, particularly for buyout funds. Jenkinson et al. (2020) show that after a few years, the unrealized values of funds' remaining investments are close estimates of the net present value of actual future cash flows, and Brown et al. (2019), suggest that, on average, unrealized values are, if anything, conservative. Both of these studies also use Burgiss data. Easton et al. (2020) present evidence that valuations are more accurate post-ASC 820.

The lack of seasoning for the more recent funds does not affect our results. We obtain qualitatively and statistically similar results when we exclude more recent vintages - those after 2012. Nevertheless, we recognize that the analysis of those funds might be subject to change in the future. ${ }^{4}$

\footnotetext{
${ }^{4}$ This is particularly true for the more recent funds given the coronavirus shock in 2020 .
} 
Table 1 also reports average performance by vintage year using three measures. The internal rate of return (IRR) is computed using the timed cash flows into and out of the fund, treating the remaining unrealized NAV (net of fees) as a final positive cash flow. The multiple of invested capital (MOIC) is the ratio of the sum of cash distributions plus remaining NAV to the cash invested in the fund. The IRR and MOIC are the standard performance measures used by PE practitioners. The third measure is the public market equivalent return (PME), which measures performance relative to a market index. We follow the approach of Kaplan and Schoar (2005) in calculating PMEs relative to the S\&P 500 total return index.

For buyout funds, the average net IRR across the sample is roughly $14 \%$ per annum, with an average MOIC of 1.80. Buyouts have consistently out-performed public markets with the average PME being 1.20 across the sample. Indeed, for each vintage year since 1994 the average PME has been greater than 1.0. Performance is somewhat lower for post-2005 vintages with an average vintage PME of 1.11. Overall, the post-2005 performance of buyouts is higher than that reported in HJK (2014 and 2016), reflecting the maturation of funds and additions to the sample.

For VC funds, the average net IRR across the sample is roughly $15 \%$ per annum, with an average MOIC of 2.11. VC funds, overall, also have out-performed public markets with the average PME of 1.22 across the sample. That performance, however, has been more variable than for buyouts. 1980s vintage years underperformed public markets; 1990s vintage years largely outperformed public markets; performance was poor, again, for vintages from 1999 to 2006; and since 2007, VC has, again, outperformed public markets.

In the final columns of Table 1, we present average performance for the subset of funds for which we have the previous fund's performance. ${ }^{5}$ Trends across these figures are similar to the full-sample results. For buyouts the performance averages are almost identical to those for the full sample. For VC, funds with a performance history have, on average, somewhat higher performance than the full sample.

Investors usually focus on relative performance when evaluating funds, often by analyzing performance quartiles by vintage year. For each vintage year, we place each of the funds in our sample in a performance quartile. We do this separately for buyout and VC funds,

\footnotetext{
${ }^{5}$ We do not require a full history of performance for all funds in a fund strategy. Provided we have performance information for at least two adjacent funds (e.g. funds 3 and 4) then these are included in our performance persistence analysis.
} 
and for each performance measure. In Table 2, we report average returns for the funds in each performance quartile.

Panel A shows that top quartile buyout funds have average PMEs of 1.81 compared to average PMEs of 0.68 for bottom quartile funds. The analogous annualized IRRs (MOICs) are $30.6 \%$ (2.74) and $-1.4 \%$ (1.00). These are large differences. Average performance is somewhat lower in the second half of the sample, so we also report the average performance by quartile for pre-2001 and post-2000 buyout funds. The PME differential between top and bottom quartiles is greater for pre-2001 funds at 1.44 than for post-2000 funds at 0.99. The IRR and MOIC differentials also are greater for pre-2001 funds.

Panel B shows that the differentials between top and bottom quartile funds have been larger for VC funds than for buyout funds. Top quartile VC funds have average PMEs of 2.60 compared to just 0.41 for bottom quartile funds. The analogous IRRs (MOICs) are 45.3\% (4.53) and $-8.2 \%(0.70)$. As with buyout funds, the PME, IRR and MOIC differentials between top and bottom quartiles are greater for pre-2001 funds.

It is worth noting that $\mathrm{VC}$ funds in the $2^{\text {nd }}$ quartile also have PMEs above 1.0, overall and for both pre-2001 and post-2000 vintages. This goes against the conventional wisdom that only the top quartile or top decile VC funds outperform public markets.

The results in Table 2 confirm that it would be extremely valuable for an LP to be able to predict and invest in those buyout and $\mathrm{VC}$ funds that will end up in the top two quartiles while avoiding funds that will end up in the bottom two quartiles. In the next section, we consider whether past performance helps investors make that prediction.

\section{Persistence based on quartile performance}

In this section, we present several different analyses of persistence, as measured by performance quartile. The analyses focus primarily on the PME performance measure. The PME is effectively a market-adjusted multiple of invested capital. It measures how an investment in a private equity funds compares to an investment in public equities. Korteweg and Nagel (2016) and Sorensen and Jagannathan (2015) provide theoretical descriptions and justifications for PME. We measure public equity performance with the return on the S\&P 500. Our results are qualitatively similar when we use the returns on the Russell 2000, an index for smaller capitalization stocks. The IRR and MOIC do not adjust for stock market movements and, 
therefore, vary meaningfully across periods of different market returns. While we focus on PME, we also show that our persistence results are qualitatively similar when we sort on and use IRR and MOIC.

We first (in sub-section A) consider the conventional wisdom of investing in funds run by GPs whose previous funds are in the top quartile as measured by PME. We study whether investors can use the information in previous performance to improve their choice of funds. As in earlier work by Kaplan and Schoar (2005) and Robinson and Sensoy (2016), we begin by considering whether the performance of a previous fund predicts the performance of the next fund.

This strategy is not strictly feasible in practice, as the final performance of the previous fund is not known at the time of fundraising. Brown et al. (2019) and Jenkinson et al. (2013) study the interaction of fundraising and interim performance, and find that interim performance is a meaningful, but imperfect measure of final performance. At the time they are asked to commit to a follow-on fund, some 3 to 5 years into the life of the current fund, investors only observe a noisy signal of ultimate performance. Accordingly, in sub-section B, we repeat our analyses using only previous fund performance information that is available when the GP is raising the next fund.

\section{A. Persistence by Quartiles - Previous Fund}

For each vintage year, we sort all funds into one of six groups. We place funds in groups one to four based on the performance quartile of its previous fund (as of June 2019) if such performance is available. If performance of the previous fund is not available, we place the fund into a fifth group if the fund sequence number is greater than one, i.e., it is not a first-time fund. We place the fund into a sixth group of first-time funds if its fund sequence number is equal to one.

\section{(i) Buyout Funds}

Panel A of Table 3 reports the crosstabs of PME quartiles of subsequent buyout funds relative to the four PME quartiles and two other classifications of the previous fund. The panel also reports the average IRR, MOIC and PME for the six different groups. For the sample as a whole there is modest persistence in buyout fund performance. Funds with a previous fund in the 
top quartile are in the top quartile $34.8 \%$, and above median $57.3 \%$, of the time. Funds with a previous fund in the bottom quartile remain in the bottom quartile $39.2 \%$, and below the median $64.5 \%$, of the time. Bottom-to-top quartile flips across successive funds occur less than $16 \%$ of the time, in either direction. A chi-square test for equality of the four previous fund quartiles is rejected at the $1 \%$ level as is a test of the equality of the top and bottom previous fund quartiles. ${ }^{6}$

In the last three columns of Panel $\mathrm{A}$, we report the average performance of funds according to our 6-way classification. Funds with a prior fund in the top quartile have an average PME of 1.30 while those whose prior fund was in the bottom quartile have an average PME of 1.01. The difference in means is significant at the $1 \%$ level. Funds previously in the second and third quartile have average PMEs for their current fund that also are significantly lower than those in the top quartile, but higher than those in the bottom quartile.

First-time funds have average performance of 1.26 that is between that of the previously top quartile and second quartile funds. Non-first-time funds for which we do not have information on previous fund performance have average performance of 1.17 which is between the performance of previously second and third quartile funds.

In the remainder of Panel $\mathrm{A}$ of Table 3, we report the analogous results for funds raised before 2001 and after 2000. The patterns are qualitatively similar in both sub-periods to the patterns overall, although it is noticeable that top quartile performance has become somewhat less persistent since 2000 and bottom quartile persistence has slightly increased.

These results have several implications. First, if one had been able to know ex ante the previous funds that would ultimately be in the top quartile, it would have been a good strategy to invest in these funds. That is consistent with the conventional wisdom. Relative to a randomized strategy of investing in buyout funds where the average PME is 1.20, a PME of 1.30 implies that the average increase in PME to be achieved from such prescience would have been 0.10 . The 0.10 difference translates into additional annualized outperformance of $2 \%$ to $2.5 \%$.

Second, the average PME of 1.26 of first-time buyout funds is above the sample average and between the performance of previous funds in the top and second quartiles. This suggests that the conventional wisdom of many LPs not to invest in first-time funds may be misguided.

\footnotetext{
${ }^{6}$ As their sample size was smaller, Kaplan and Schoar (2005) analyzed performance according to terciles.
} 
Third, it is worth noting that there is a large attrition rate for bottom quartile funds. Of the funds raised that have previous fund performance, only 16\% (not 25\%) were previously in the bottom quartile. This reflects exit by the poorly performing GP, or a decision by the LPs in our sample to avoid subsequent funds from poorly performing GPs. This is consistent with the results in Kaplan and Schoar (2005) and Chung et al. (2011) that the ability to raise a subsequent fund is significantly related to past performance.

\section{(ii) VC Funds}

Panel B of Table 3 repeats the analysis for the $\mathrm{VC}$ funds in our sample. For the entire sample, there is marked persistence in VC fund performance. Funds with a previous fund in the top quartile, again as measured by PME, are in the top quartile and above median, respectively, $45 \%$ and $69 \%$ of the time. Bottom-to-top quartile and top-to-bottom quartile flips occur less than $13 \%$ of the time. A chi-square test for equality of the four previous fund quartiles is rejected at the $1 \%$ level as is a test of the equality of the top and bottom previous fund quartiles.

Funds previously in the top quartile have an average PME of 2.06 while funds previously in the bottom quartile have an average PME of only 0.67. The difference in means is significant at the $1 \%$ level. Bottom quartile funds also have a much higher attrition rate in our sample: there are $219 \mathrm{VC}$ funds whose previous funds were top quartile in our sample, but there are only 118 funds whose previous funds were bottom quartile. Funds in the second and third quartile have significantly lower average PMEs than those in the top quartile, and significantly higher than those in the bottom quartile. First-time funds have average performance roughly equal to the average performance of funds in the second quartile. Funds that do not have previous performance but are not first-time funds have average PMEs between those of third and fourth quartile funds.

It is worth noting that, across the whole sample, funds in the top three quartiles have average PMEs that exceed one. This, too, is at odds with the conventional wisdom that only top quartile VC funds have beaten the S\&P 500.

In the remainder of Panel B of Table 3, we report the analogous results for funds raised before 2001 and after 2000. The patterns are generally qualitatively similar in terms of performance persistence. However, there has been a marked drop in average returns since 2000, across all the performance measures. As a result, more recently only the top quartile VC funds 
have significantly beaten public market returns. However, the extent of the outperformance - a PME of 1.57 - is substantial, and far higher than for buyout funds over this later period.

\section{B. $\quad$ Persistence by Quartiles - Previous Fund at Fundraise}

The investigation in the previous section replicates the type of analyses in previous work on persistence. However, previous work and our initial analyses use the latest available performance information for the current and prior funds. The analyses do not use the performance information that actually would have been available to LP investors at the time they had to make the decision to invest in a fund.

In this section, we use the performance information that would have been available to LPs at the time of fundraising. Specifically, we use the performance of the previous fund measured two quarters before the first capital call of the current fund. Because fund performance is typically reported with a lag of a quarter, this represents the information a potential LP would have about the previous fund one quarter before the first investment in the current fund. We believe this represents the likely time when many, if not most, LPs finalize their commitment to the current fund. Panels A and B of Table 4 report the results for buyout funds and VC funds respectively. The results are not sensitive to using performance results from one quarter earlier or later. 
The results for buyout funds are markedly different from the results in Table 3. For funds raised before 2001, there is evidence of performance persistence: nearly $37 \%$ of funds reporting top quartile performance at the time of fundraising produced top quartile returns in their next fund. However, performance persistence disappeared for post-2000 vintage buyout funds. As a result, in the overall sample, when funds are sorted by the performance quartile of the GP's previous funds at the time of fundraising, performance of the current buyout fund is statistically indistinguishable regardless of quartile. This is particularly true for investment multiples, which are tightly clustered across the previous fund quartiles between 1.73 and 1.78. The differences between top- and bottom-quartile funds are also statistically indistinguishable. Moreover, returns for buyout funds in all previous fund quartiles exceed those of public markets as measured by the S\&P 500. The conventional wisdom, therefore, does not appear to hold for buyout funds.

First-time funds perform at least as well as any quartile. This again calls into question the common practice among many LPs of not investing in first-time funds.

Panel A of Table 4 also evinces one other strong pattern. Very few GPs raise a fund when the performance of the previous fund is in the bottom quartile. Post-2000, only 33 of 359 or $9 \%$ of funds with previous fund performance were in the bottom quartile at the time of fundraising. Similarly, only 118 of 359 or $33 \%$ were below median. To understand the extent of that timing, Table 3 indicates that almost twice as many firms - 57 - that raised funds post-2000 ended up having a previous fund in the bottom quartile. This is consistent with LPs being less likely to invest in a new fund of a GP whose previous fund is performing poorly. It also is consistent with a GP choosing not to try to raise a new fund when its previous fund is performing poorly.

\section{(ii) VC Funds}

Panel B of Table 4 indicates that significant persistence persists for VC funds using performance at the time of fundraising. Overall, funds with previous funds in the top quartile have an average PME of 1.70 while those with previous funds in the bottom quartile have average PMEs of 0.91. When funds are sorted by the performance quartile of the GP's previous funds at the time of fundraising, a chi-square test is significant at the $6 \%$ level. A chi-square test for the 
difference in the top- and bottom-quartile funds is also statistically significant at the $6 \%$ level. The average PME for top quartile funds are significantly greater than those of the second, third and fourth quartiles funds.

The patterns are qualitatively similar over both sub-periods. However, the magnitude of persistence is lower post-2000 with previous top quartile funds having an average PME of 1.20 and previous bottom quartile funds having an average PME of 0.91. Pre-2001, the chi-square test for all four quartiles is significant at the 3\% level. Post-2000, the chi-square test for all four quartiles is not significant, but the difference of the top- and bottom-quartile fund distributions and their average PMEs are statistically different at the $10 \%$ level.

Three other patterns are worth noting.

First, for the overall sample, first-time funds have an average PME of 1.24 close to the average for previous funds in the $2^{\text {nd }}$ quartile. Post-2000, first-time funds do even better with an average PME of 1.23 that exceeds (albeit not significantly) the average PME of those with previous top quartile funds. As with buyouts, this calls into question the common practice among many LPs of not investing in first-time funds.

Second, there also is a belief among some LPs that only top quartile (and, perhaps, top decile) VC funds are worth investing in. This belief is not supported in the patterns in panel B. Funds previously in the $2^{\text {nd }}$ quartile have an average PME of 1.33 , overall, and 1.15 post-2000, indicating that such funds were worth investing in if the goal was to beat public markets.

Finally, for VC funds, like buyout funds, relatively few GPs raise a fund when the performance of the previous fund is poor. Over the entire sample, only 77 of 726 or $11 \%$ of funds with previous fund performance were in the bottom quartile at the time of fundraising. Similarly, only 240 of 726 or $33 \%$ were below median. To understand that extent of that timing, Table 3 indicates that $60 \%$ more firms - 118 - that raised VC funds ended up having a previous fund in the bottom quartile. Again, this is consistent with LPs being less likely to invest in a new fund of a GP whose previous fund is performing poorly. It also is consistent with a GP choosing not to try to raise a new fund when its previous fund is performing poorly.

\section{(iii) Performance at fundraising compared to final performance}

The reason we find persistence for buyouts and $\mathrm{VC}$ when using final performance of the previous fund, but no persistence for buyouts and weaker persistence for VC using performance at fundraising is that performance changes over time. In Table 5, we present the transition matrix 
for previous funds from the time of fundraising to final performance (or, for funds that are not fully realized, the most recent performance as of June 2019).

Panel A of Table 5 shows that only $57 \%$ of buyout funds that presented top-quartile numbers at the time of fundraising ultimately turned out to be top quartile performers. And almost $23 \%$ of the buyout funds that were in the bottom quartile at the time of fundraising ended up above median. For post-2000 funds, the percentage is $24 \%$. Similarly, over $1 / 3$ of the buyout funds that were in the third quartile at fundraising ended up above median, both overall and post2000. Panel B of Table 5 shows qualitatively similar patterns for VC funds. Therefore, the performance information that LPs have available to them at the time of fundraising is not a very reliable indicator of the final relative performance of the funds.

\section{Persistence by Quartiles - Second Previous Fund at Fundraise}

The previous section indicates that the performance of the previous fund at the time of fundraising is not informative about current fund performance for buyout funds, but is informative for $\mathrm{VC}$ funds. At the time of fundraising, however, LPs potentially also have access to the performance of the second previous fund (if the GP has such a fund). It is possible that the performance of the second previous fund at fundraising is informative, particularly for buyouts.

The relation of current fund performance to that of the second previous fund is particularly interesting for two additional reasons. First, the second previous fund is almost certainly more fully realized than the first previous fund, potentially providing a more accurate measure of GP performance.

Second, it is possible that the current and previous funds of a private equity GP include investments in the same company. This is particularly common in $\mathrm{VC}$ funds. If some of these investments are particularly successful or unsuccessful, they might mechanically induce persistence across current and previous funds. Investments are much less likely to coincide in the current fund and the second previous fund. The presence of performance persistence between the current fund and the second previous fund, therefore, would be stronger evidence of persistent skill rather than a mechanical relationship.

In Table 6, we repeat the analysis presented in Table 4 using the performance of the second previous fund at fundraising. Inevitably, this results in a smaller sample size, as we lose all $2^{\text {nd }}$ funds from our analysis (in addition to first-time funds). 


\section{(i) Buyout funds}

Across the whole sample of buyout funds, Panel A of Table 6 shows no evidence of persistence from the second previous fund to the current fund. Funds with second previous funds in the top quartile actually have a lower average PME (1.14), than funds in the second and third quartiles. A chi-square test for differences across the four quartiles is not significant. Post-2000 funds also provide no evidence whatsoever of persistence. Second previous funds in the third quartile have the highest average PMEs.

As with the first previous fund, GPs with better performing second previous funds are more likely to raise new funds while those with worse performing second previous funds are not. Post-2000, only 23 of 212 or $11 \%$ of funds raised have second previous funds in the bottom quartile; only 72 of 212 or $33 \%$ are below median. Again, this is consistent with LPs being less likely to invest in a new fund of a GP whose previous fund is performing poorly or with a GP choosing not to try to raise a new fund when its previous fund has performed poorly.

\section{(ii) VC funds}

Panel B of Table 6 performs a similar analysis for VC funds. Across the whole sample, there is a significant persistence from the second previous fund to the current fund. Funds with second previous funds in the top quartile have the highest average PME of 1.75 and more than $60 \%$ had performance above the sample median. In contrast, fewer than $38 \%$ of VC funds with second previous funds in the bottom quartile outperformed the median and had an average PME of 0.74 . The average PME of the previous top quartile funds are significantly greater than that of the second previous third quartile and bottom quartile funds at the 5\% level. A chi-square test comparing the top to bottom quartile is significant at the 5\% level. A chi-square test comparing all four quartiles is not significant.

The patterns of persistence are qualitatively similar for pre-2001 and post-2000 funds, although the extent of top-quartile persistence is noticeably greater for funds raised before 2001 . In both sub-periods the funds with second previous funds in the top quartile have the highest average PME while the funds with the second previous funds in the bottom quartile have the lowest average PMEs. The differences are statistically significant for both subperiods. The average PMEs of the second previous top quartile funds are significantly greater than the second previous third quartile funds pre-2001 and the second previous second quartile funds post-2000. 
The chi-square tests comparing the top to bottom quartiles are significant at the $10 \%$ level post2000, but not pre-2001. The chi-square tests comparing all four quartiles are not significant.

As with the buyout funds, GPs with worse performing second previous funds are less likely to raise new funds. Only 40 of 462 or $9 \%$ of funds raised had second previous funds in the bottom quartile.

\section{Sensitivity}

In this section, we discuss the sensitivity of our results to different performance measures, to excluding more recent funds, and to different time periods.

\section{(i) Different performance measures: IRR and MOIC}

Our analysis has focused on performance as measured by PME, as we consider this to be the most meaningful metric. Industry practice, however, continues to focus on IRRs and MOICs. Accordingly, in Tables 7 and 8, we repeat our persistence analyses in Table 4 but using IRRs and MOICs as the performance measure. The patterns are qualitatively similar to the patterns using PMEs.

For buyout funds, when we measure performance by IRR (Table 7, Panel A), the probability of repeating top quartile performance in successive funds is $22 \%$ and the probability of repeating above median performance is $52 \%$ for the sample overall. Post-2000, the analogous percentages are similar at $21 \%$ and $51 \%$. There is some difference in average performance across quartiles pre-2001, but none post-2000, consistence with persistence having disappeared. Chisquare tests comparing all four quartiles and the top to bottom quartiles are all insignificant at the $10 \%$ level.

For buyout funds, when we measure performance by MOIC (Table 8, Panel A), top quartile persistence is $26 \%$ and the probability of repeating above median is $48 \%$ for the sample overall. Post-2000, the analogous percentages are similar at $26 \%$ and $47 \%$. Again, there is some difference in average performance across quartiles pre-2001, but none post-2000, consistent with persistence having disappeared. Chi-square tests comparing all four quartiles and the top to bottom quartiles also are all insignificant at the $10 \%$ level. 
Overall, then, the persistence results for buyouts using IRR and MOIC are qualitatively identical to those using PME. Persistence at the time of fundraising is weak overall and nonexistent post-2000.

For VC funds, when we measure performance by IRR (Table 7, Panel B), the probability of repeating top quartile performance in successive funds is $32 \%$ and the probability of repeating above median is $58 \%$ for the sample overall. Average performance is strongest for top quartile funds. Persistence is more modest post-2000, with top quartile funds repeating in the top quartile $27 \%$ of the time and above median 52\%. Average performance is greater for top (and second) quartile funds relative to bottom (and third quartile) funds. Chi-square tests comparing all four quartiles are significant at the $1 \%$ level overall and for both sub-periods.

For VC funds, when we measure performance by MOIC (Table 8, panel B), top quartile persistence is $34 \%$ and the probability of repeating above median is $57 \%$ for the sample overall. Average performance is greater for top quartile funds on all three metrics. Post-2000, the analogous percentages are similar at 29\% and 55\%. Average IRR and MOIC is greatest for top quartile funds. Average PMEs, however, are not significantly higher. In addition, all chi-square tests are insignificant.

Overall, then, the persistence results for VC using IRR are qualitatively identical to those using PME. The results are less strong using MOIC.

\section{(ii) Excluding more recent funds}

Our second sensitivity test relates to the treatment of unrealized investments. In our primary analyses, we exclude funds with vintage years after 2014. However, the funds of the more recent vintages in our sample are still largely unrealized, particularly the VC funds. This could affect our post-2000 results. Consequently, we repeat our analyses excluding funds from the 2013 and 2014 vintages. We obtain qualitatively and statistically identical results for both buyout and VC funds. These results are available upon request. This suggests that the results are not likely to be explained by the fact that some of the post-2000 funds are not fully realized.

\section{(iii) Different time periods}

As we mentioned in the introduction, much of the previous research on persistence used funds raised before 2000. That is the reason we chose $2000 / 2001$ as the breakpoint for our 
analysis - dividing funds into those raised pre-2001 and those raised post-2000. Given that 2000 / 2001 was the period of the dot-com crash and a recession, it is possible that our post-2000 results are sensitive to the breakpoint. We performed sensitivity analyses to address this possibility.

First, we chose 2003 as the breakpoint year, looking at funds raised pre-2004 and post2003. For both buyout and VC funds, the results are qualitatively and statistically identical, and are available upon request.

Second, we looked at performance using funds raised in rolling eight-year periods beginning with 1993 to 2000 and going until 2007 to 2014 . For both buyout and VC funds, the results for the earlier periods are qualitatively similar to the results for the pre-2001 sample while the results for the later periods are qualitatively similar to the results for the post-2000 sample.

\section{Persistence regressions}

To this point, we have focused on quartile transition probabilities between performance groupings, variously defined. While this is a common practice among practitioners, an alternative approach is to use a linear regression, relating current performance to past performance. This also allows us to control for other factors that might affect how fund returns evolve over time for a particular GP. In this section, we estimate regressions using log PME to measure performance (reflecting the fact that the distribution of PME is right skewed). Keeping with the intention of using information actually available to LPs, we use previous fund performance at fundraising or 2 nd previous fund performance as explanatory variables. In some specifications we also include the dummy variables to capture if the GP is raising a fund more than 50\%, and more than 100\%, larger than its prior fund. These dummies are cumulative, in the sense that a fund that increases in size by, say, $120 \%$ will have a value of 1 for each dummy. The regressions include vintage year dummy variables for both the current and previous funds. This approach measures persistence across the whole sample of funds.

\section{(i) Buyout funds}

Panel A of Table 9 reports previous fund performance regressions for the whole sample period; Panels B and C repeat the analyses, respectively, for pre-2001 and post-2000 vintage funds. For the whole sample of buyout funds, previous fund PME and second previous fund 
PME at fundraising and change in fund size at fundraising are not related to current fund PME. This result holds whether or not dummies for fund size increases or secondary fund style are included. In general, our results suggest that performance is lower for such secondary style buyout funds. We also find little effect of significant changes in fund size impacting returns.

Surprisingly, given our earlier findings using fund quartiles, for post-2000 vintages, current fund PME is related to the previous fund PME with a significant coefficient of 0.194 (or 0.173 including the controls for the change in fund size and secondary fund styles) as shown in Panel C. This suggests there is some persistence for PMEs that is independent of previous fund quartile. In other words, even if they are not top (bottom) quartile, funds with higher (lower) previous fund PMEs, subsequently do better (worse). The effect, however, is economically modest. An additional previous fund PME of 0.20 (or roughly $4 \%$ per year) is associated with an additional PME in the current fund of less than 0.04 (or less than $1 \%$ per year). We find no significant effect from the 2nd previous fund PME.

To understand better where the persistence comes from, we sorted post-2000 buyout funds roughly into quartiles based on previous fund PME at fundraising. The cutoffs we used to do this were previous fund PMEs above $1.35,1.15$ to $1.35,1$ to 1.15 and below 1 . The average current fund PMEs of these groups were, respectively, 1.23, 1.17, 1.17 and 1.10. The difference between the top and bottom group is significant at the $5 \%$ level. There is no statistical difference between the performances of the top, second and third groups.

Although we do not report them, regression results are generally statistically and economically weaker when we use IRR and MOIC instead of PME.

Overall, then, post-2000, the regression results suggest there is at best modest persistence with previous fund PME that is not picked up in quartile performance. That persistence is primarily persistence of the bottom quartile of absolute performance. LPs would have done well to avoid those funds. There is still no evidence of reliable outperformance by the top previous performers.

\section{(ii) Venture Capital Funds}

The right half of Table 9 reports regression results for $\mathrm{VC}$ funds. For the entire sample period, Panel A shows that previous fund PME is significantly related to current fund PME. The 
relationship is similar in both sub-periods. The coefficient of 0.339 in Panel A implies that a 0.20 increase in previous fund PME is associated with a 0.068 increase in current fund performance.

Second previous fund PME also is positively related to performance overall and in the pre-2001 sub-periods. The relation, however, is economically small and not significant in the post-2000 period as shown in Panel C.

When we control for change in fund size, the coefficients on size variables are not significant in the overall sample, suggesting that returns are not significantly impacted by increased fund sizes. This is consistent with VC firms being disciplined in not increasing fund size too fast, to the detriment of returns. There is some weak evidence of a negative size effect pre-2001 as shown in Panel B, consistent with the funds having over-expanded in the dot-com era. Unlike the results for buyouts, we find no significant impact on PMEs associated with secondary fund styles for VC.

Although we do not report them, regression results are, in general, statistically and economically weaker when we use IRR and MOIC instead of PME.

Overall, then, the regression results for $\mathrm{VC}$ funds are consistent with the previous results by fund quartile.

\section{Summary and Implications}

This paper presents new evidence on the persistence of U.S. private equity (buyout and venture capital) funds using cash-flow data sourced from a large sample of institutional investors. Using ex post or most recent fund performance (as of June 2019), we confirm the previous findings on persistence overall as well as for pre-2001 and post-2000 funds.

However, when we look at the information an investor would actually have - previous fund performance at the time of fundraising rather than final performance - we find little evidence of persistence, for buyouts, both overall and post-2000. The conventional wisdom to invest in funds that are, at the time of fundraising, reporting top quartile returns does not hold for buyouts. This occurs because buyout firms raise next funds when the performance of their previous funds is strong. For post-2000 buyout funds, the PME regressions, unlike those using quartiles, indicate there is modest persistence. The persistence, however, is driven by the persistence of funds in the bottom quartile of the previous PME distribution. There is no 
statistical difference in performance among previous funds in the top three quartiles of previous PME performance.

In contrast, we do find persistence for $\mathrm{VC}$ funds using the performance of both the previous and the second previous fund at fundraising.

Our results have implications for buyout and VC fund investors.

First, little buyout fund persistence combined with a continuation of above public market returns for buyout is consistent with at least two explanations. It is possible that the buyout business has changed, with operating engineering becoming increasingly important (see Kaplan and Stromberg (2009)). Some general partners adjusted while others did not. Alternatively, it is possible that general partners learned from each other and that has led to the lack of persistence.

Second, our persistence results in U.S. buyout funds casts doubt on the industry rule of thumb to invest only in funds that were previously in the top quartile. To the extent buyout investors use past performance, they should focus on previous fund PME, rather than previous fund quartile, and should avoid bottom quartile performers.

Third, the lack of a performance-size relation suggests that buyout funds have been able to scale their performance as they have become larger. PMEs in the post-2000 period are not appreciably different from those in the earlier period despite larger fund sizes.

Our results on VC funds have two implications. First, the persistence of persistence in VC suggests that the industry rule of thumb to invest with GPs that have previously performed well and to avoid those that have not remains consistent with our results. The stronger performance persistence for VC as compared to buyout suggests that GP skills and networks for successful $\mathrm{VC}$ investing are harder to replicate than is true in buyout.

At the same time however, $\mathrm{VC}$ funds with previous performance in both the top and second quartiles outperform the S\&P 500. This is not consistent with the view that only very few VC funds outperform. In fact, previous funds that are above median appear to do so. 


\section{References}

Brown, Greg, Oleg Gredil and Steven N. Kaplan, 2019, Do Private Equity Funds Manipulate Returns? Journal of Financial Economics, Volume 132, 267-297.

Chung, J., Performance Persistence in Private Equity Funds. Working paper, Chinese University of Hong Kong.

Chung, J., B. Sensoy, L Stern and M. Weisbach, 2012, Pay for Performance from Future Fund Flows: The Case of Private Equity. Review of Financial Studies, 25, 3259-3304.

Cornelius, P., 2011, International Investments in Private Equity: Asset Allocation, Markets, and Industry Structure. London, UK: Academic Press.

Easton, P., S. Larocque and J. Stevens, 2020, Private Equity Valuation Before and After ASC 820 ,

papers.ssrn.com/sol3/papers.cfm?abstract_id=3314992.

Harris, R., T. Jenkinson, and R. Stucke, 2010, A White Paper on Private Equity Data and Research. UAI Foundation Working Paper, University of Virginia.

Harris, Robert S., Tim Jenkinson, and Steven N. Kaplan, 2014, Private Equity Performance: What Do We Know? Journal of Finance, October, 1851-1882.

Harris, Robert S., Tim Jenkinson, and S. N. Kaplan, 2016, "How Do Private Equity Investments Perform Compared to Public Equity?” Journal of Investment Management 14, 1-24.

Harris, Robert S., Tim Jenkinson, S. N. Kaplan and R. Stucke, 2018, Financial Intermediation in Private Equity: How Well Do Funds of Funds Perform? Journal of Financial Economics 129, 287-305.

Jegadeesh, N., R. Kraussl, and J. Pollet, 2009, Risk and Expected Returns of Private Equity Investments: Evidence Based on Market Prices. Journal of Finance.

Jenkinson, Tim, Wayne Landsman, Brian Rountree, and Kazbi Soonawalla, 2020, Private Equity Net Asset Values and Future Cash Flows. The Accounting Review 95, 191-210

Jenkinson, Tim, Miguel Sousa, and Rudiger Stucke, 2013, How Fair are the Valuations of Private Equity Funds? Working Paper, Oxford University.

Jones, C. and M. Rhodes-Kropf, 2004, The Price of Diversifiable Risk in Venture Capital and Private Equity. Working Paper, Columbia University 
Kaplan, S. N. and B. Sensoy, 2015. Private Equity Performance: A Survey. Annual Review of Financial Economics, Volume 7, 597-614.

Kaplan, S. N., and A. Schoar, 2005. Private Equity Returns: Persistence and Capital flows. Journal of Finance 60, 1791-1823.

Kaplan, S.N. and P. Strömberg, 2009, Leveraged Buyouts and Private Equity. Journal of Economic Perspectives, Winter, 121-146.

Kocis, James M., James C. Bachman, Austin M. Long and Craig J. Nickels, 2009, Inside Private Equity. Hoboken, N.J., USA: John Wiley \& Sons, Inc.

Korteweg, Arthur and Stefan Nagel, 2016, Risk-Adjusting the Returns to Venture Capital. Journal of Finance 71, 1437-1470.

Korteweg, Arthur and Morten Sorensen, 2010. Risk and Return Characteristics of Venture Capital-Backed Entrepreneurial Companies. Review of Financial Studies.

Lerner, Josh, Antoinette Schoar and Wan Wongsunwai, 2007, Smart Institutions, Foolish Choices? The Limited Partner Performance Puzzle. Journal of Finance 62, 731-64.

Ljungqvist, A. and M. Richardson, 2003, The Cash Flow, Return, and Risk Characteristics of Private Equity. Working Paper No. 9495, NBER.

Ljungqvist, A., M. Richardson, and D. Wolfenzon, 2007, The Investment Behavior of Buyout Funds: Theory and Evidence.

Metrick, Andrew, and Ayako Yasuda, 2010, The Economics of Private Equity Funds. Review of Financial Studies 23, 2303-2341.

Mulcahy, D., B. Weeks and H. Bradley, 2012, "We Have Met the Enemy .... and He Is Us. Lessons from Twenty Years of the Kauffman Foundation's Investments in Venture Capital Funds and The Triumph of Hope over Experience." Working paper, Kauffman Foundation.

Nanda, R., S. Samila and O. Sorensen, forthcoming, The Persistent Effect of Initial Success: Evidence from Venture Capital. Journal of Financial Economics.

Phalippou, Ludovic and Oliver Gottschalg, 2009, The Performance of Private Equity Funds. Review of Financial Studies 22, 1747-1776.

Robinson, D. and B. Sensoy, 2016. Cyclicality, Performance Measurement, and Cash Flow Liquidity in Private Equity. Journal of Financial Economics 122, 521-543. 
Robinson, David and Berk Sensoy, 2013. Do Private Equity Fund Managers Earn their Fees? Compensation, Ownership, and Cash Flow Performance. Review of Financial Studies 26, 2760-2797.

Sensoy, Berk, Y. Wang, and M. S. Weisbach, 2014. Limited Partner Performance and the Maturing of the Private Equity Industry. Journal of Financial Economics 112, 320-343.

Sorensen, Morten and Ravi Jagannathan, 2015. The Public Market Equivalent and Private Equity Performance. Financial Analysts Journal 71, 43-50

Stucke, R., 2011, Updating History. Working Paper, Oxford University

Swensen, D. 2000, Pioneering Portfolio Management: An Unconventional Approach to Institutional Investment. Free Press. 


\section{Table 1: Summary Information on Funds}

This table provides summary information on the sample of funds and their average performance. All data is provided by Burgiss. Buyout funds (VC funds) are summarized in Panel A (Panel B): the sample includes 893 (1329) funds, and for 484 (726) of these funds there is a prior fund that can be used to measure performance persistence. Funds are classified by their vintage year, which is defined as the date when the fund first draws down capital from its investors. The $\%$ unrealized column measures the ratio of the remaining net asset value (NAV) reported by the fund, to the sum of the cash returned to investors plus the NAV. The cash flows and NAVs are updated as of June 30, 2019. For each vintage year three performance measures are provided. The average Internal Rate of Return (IRR); the Multiple of Invested Capital (MOIC), and the Public Market Equivalent (PME) return. The MOIC is defined as the ratio of (a) the cash returned to investors plus the remaining NAV, to (b) the cash invested by investors. The PME is computed in the same way as Kaplan and Schoar (2005), using the total return of the S\&P 500 as the market index.

\section{Panel A: Buyout Funds}

\begin{tabular}{|c|c|c|c|c|c|c|c|c|c|c|}
\hline Vintage & Total & $\begin{array}{l}\text { Avg. Capital } \\
\text { Committed } \\
(\$ \mathrm{~m})\end{array}$ & $\frac{\%}{\text { Unrealized }}$ & $\begin{array}{c}\text { Average } \\
\text { IRR } \\
\%\end{array}$ & $\begin{array}{c}\text { Average } \\
\text { MOIC }\end{array}$ & $\begin{array}{c}\text { Average } \\
\text { PME }\end{array}$ & $\begin{array}{c}\text { Funds with } \\
\text { Performance } \\
\text { History }\end{array}$ & $\begin{array}{c}\text { Average } \\
\text { IRR } \\
\%\end{array}$ & $\begin{array}{c}\text { Average } \\
\text { MOIC }\end{array}$ & $\begin{array}{c}\text { Average } \\
\text { PME }\end{array}$ \\
\hline 1984 & 2 & & & & & & 1 & & & \\
\hline 1985 & 4 & & & & & & 1 & & & \\
\hline 1986 & 4 & & & & & & 2 & & & \\
\hline 1987 & 8 & 1,042 & $0 \%$ & $17.7 \%$ & 3.26 & 1.31 & 5 & $16.5 \%$ & 3.05 & 1.26 \\
\hline 1988 & 9 & 674 & $0 \%$ & $11.1 \%$ & 1.77 & 0.80 & 2 & & & \\
\hline 1989 & 10 & 276 & $0 \%$ & $21.3 \%$ & 2.42 & 1.28 & 2 & & & \\
\hline 1990 & 8 & 288 & $0 \%$ & $16.2 \%$ & 2.23 & 0.99 & 0 & & & \\
\hline 1991 & 4 & & & & & & 1 & & & \\
\hline 1992 & 9 & 446 & $1 \%$ & $22.3 \%$ & 1.97 & 1.08 & 3 & & & \\
\hline 1993 & 8 & 570 & $0 \%$ & $15.6 \%$ & 1.90 & 0.93 & 3 & & & \\
\hline 1994 & 17 & 359 & $0 \%$ & $16.0 \%$ & 1.82 & 1.04 & 9 & $19.3 \%$ & 2.05 & 1.14 \\
\hline 1995 & 27 & 629 & $0 \%$ & $13.2 \%$ & 1.65 & 1.09 & 9 & $9.8 \%$ & 1.43 & 1.00 \\
\hline 1996 & 17 & 280 & $0 \%$ & $13.3 \%$ & 1.64 & 1.15 & 6 & $4.7 \%$ & 1.25 & 0.88 \\
\hline 1997 & 29 & 927 & $0 \%$ & $3.9 \%$ & 1.26 & 1.08 & 19 & $6.0 \%$ & 1.37 & 1.14 \\
\hline 1998 & 39 & 886 & $0 \%$ & $5.8 \%$ & 1.47 & 1.36 & 21 & $6.2 \%$ & 1.48 & 1.34 \\
\hline 1999 & 35 & 950 & $1 \%$ & $4.9 \%$ & 1.40 & 1.20 & 17 & $0.9 \%$ & 1.23 & 1.05 \\
\hline 2000 & 51 & 1,189 & $1 \%$ & $13.3 \%$ & 1.77 & 1.41 & 22 & $14.2 \%$ & 1.86 & 1.45 \\
\hline 2001 & 27 & 756 & $1 \%$ & $19.1 \%$ & 1.83 & 1.39 & 14 & $17.6 \%$ & 1.81 & 1.32 \\
\hline 2002 & 20 & 728 & $3 \%$ & $18.9 \%$ & 1.93 & 1.43 & 9 & $16.1 \%$ & 1.80 & 1.32 \\
\hline 2003 & 24 & 920 & $3 \%$ & $18.5 \%$ & 2.10 & 1.53 & 13 & $21.0 \%$ & 1.96 & 1.49 \\
\hline 2004 & 37 & 883 & $5 \%$ & $11.1 \%$ & 1.71 & 1.27 & 19 & $12.6 \%$ & 1.81 & 1.35 \\
\hline 2005 & 60 & 841 & $7 \%$ & $11.1 \%$ & 1.76 & 1.23 & 30 & $11.8 \%$ & 1.77 & 1.27 \\
\hline 2006 & 56 & 2,279 & $10 \%$ & $7.8 \%$ & 1.61 & 1.04 & 33 & $9.5 \%$ & 1.69 & 1.06 \\
\hline 2007 & 68 & 1,748 & $13 \%$ & $12.4 \%$ & 1.79 & 1.08 & 33 & $13.5 \%$ & 1.83 & 1.12 \\
\hline 2008 & 65 & 1,587 & $20 \%$ & $13.2 \%$ & 1.75 & 1.02 & 38 & $14.5 \%$ & 1.85 & 1.06 \\
\hline 2009 & 22 & 837 & $25 \%$ & $17.9 \%$ & 2.03 & 1.16 & 17 & $20.4 \%$ & 2.13 & 1.24 \\
\hline 2010 & 29 & 681 & $29 \%$ & $12.7 \%$ & 1.70 & 1.02 & 20 & $11.8 \%$ & 1.67 & 0.99 \\
\hline 2011 & 46 & 1,311 & $39 \%$ & $20.7 \%$ & 2.04 & 1.26 & 33 & $20.7 \%$ & 2.05 & 1.27 \\
\hline 2012 & 47 & 1,326 & $44 \%$ & $18.1 \%$ & 1.72 & 1.16 & 29 & $18.8 \%$ & 1.72 & 1.16 \\
\hline 2013 & 45 & 1,570 & $58 \%$ & $18.3 \%$ & 1.58 & 1.15 & 35 & $18.1 \%$ & 1.55 & 1.13 \\
\hline 2014 & 60 & 1,138 & $72 \%$ & $17.6 \%$ & 1.51 & 1.14 & 37 & $16.5 \%$ & 1.49 & 1.13 \\
\hline $\begin{array}{l}\text { Overall } \\
\text { Sample }\end{array}$ & 893 & 1,127 & $18 \%$ & $14.2 \%$ & 1.80 & 1.20 & 484 & $14.2 \%$ & 1.76 & 1.18 \\
\hline
\end{tabular}


Table 1: Summary Information on Funds (continued)

\section{Panel B: Venture Capital Funds}

\begin{tabular}{|c|c|c|c|c|c|c|c|c|c|c|}
\hline Vintage & Total & $\begin{array}{l}\text { Avg. Capital } \\
\text { Committed } \\
(\$ \mathrm{~m})\end{array}$ & $\begin{array}{l}1 \% \\
\text { Unrealized }\end{array}$ & $\begin{array}{c}\text { Average } \\
\text { IRR }\end{array}$ & $\begin{array}{c}\text { Average } \\
\text { MOIC }\end{array}$ & $\begin{array}{c}\text { Average } \\
\text { PME }\end{array}$ & $\begin{array}{c}\text { Funds with } \\
\text { Performance } \\
\text { History }\end{array}$ & $\begin{array}{c}\text { Average } \\
\text { IRR }\end{array}$ & $\begin{array}{c}\text { Average } \\
\text { MOIC }\end{array}$ & $\begin{array}{c}\text { Average } \\
\text { PME }\end{array}$ \\
\hline 1984 & 22 & 67 & $0 \%$ & $6.9 \%$ & 1.67 & 0.65 & 10 & $6.3 \%$ & 1.60 & 0.61 \\
\hline 1985 & 26 & 41 & $0 \%$ & $7.6 \%$ & 2.03 & 0.70 & 7 & $12.7 \%$ & 2.70 & 0.89 \\
\hline 1986 & 24 & 47 & $0 \%$ & $9.7 \%$ & 1.99 & 0.85 & 7 & $8.8 \%$ & 1.76 & 0.74 \\
\hline 1987 & 26 & 55 & $0 \%$ & $10.7 \%$ & 2.16 & 0.91 & 5 & $20.5 \%$ & 3.43 & 1.48 \\
\hline 1988 & 27 & 67 & $0 \%$ & $12.1 \%$ & 2.02 & 0.95 & 12 & $18.9 \%$ & 2.63 & 1.30 \\
\hline 1989 & 25 & 60 & $0 \%$ & $16.6 \%$ & 2.54 & 1.16 & 16 & $18.2 \%$ & 2.68 & 1.31 \\
\hline 1990 & 13 & 64 & $0 \%$ & $25.1 \%$ & 3.04 & 1.52 & 9 & $28.3 \%$ & 3.28 & 1.61 \\
\hline 1991 & 6 & 69 & $0 \%$ & $19.6 \%$ & 2.63 & 1.09 & 3 & & & \\
\hline 1992 & 17 & 84 & $0 \%$ & $23.7 \%$ & 3.19 & 1.49 & 14 & $13.2 \%$ & 1.90 & 0.87 \\
\hline 1993 & 20 & 96 & $0 \%$ & $40.1 \%$ & 5.35 & 2.34 & 13 & $49.2 \%$ & 6.67 & 2.81 \\
\hline 1994 & 16 & 92 & $0 \%$ & $48.1 \%$ & 6.15 & 2.81 & 12 & $52.6 \%$ & 7.16 & 3.22 \\
\hline 1995 & 28 & 135 & $0 \%$ & $61.3 \%$ & 5.54 & 3.10 & 16 & $46.8 \%$ & 3.45 & 2.03 \\
\hline 1996 & 18 & 131 & $0 \%$ & $92.1 \%$ & 6.68 & 4.17 & 10 & $115.4 \%$ & 9.98 & 6.25 \\
\hline 1997 & 45 & 131 & $0 \%$ & $77.4 \%$ & 3.63 & 2.85 & 19 & $120.1 \%$ & 5.33 & 4.21 \\
\hline 1998 & 53 & 195 & $1 \%$ & $29.3 \%$ & 1.96 & 1.76 & 35 & $37.4 \%$ & 2.37 & 2.12 \\
\hline 1999 & 90 & 311 & $2 \%$ & $-3.6 \%$ & 0.87 & 0.75 & 47 & $-2.6 \%$ & 0.87 & 0.77 \\
\hline 2000 & 117 & 361 & $3 \%$ & $-3.4 \%$ & 0.92 & 0.71 & 60 & $-1.9 \%$ & 0.96 & 0.72 \\
\hline 2001 & 60 & 366 & $7 \%$ & $1.3 \%$ & 1.32 & 0.86 & 36 & $1.5 \%$ & 1.37 & 0.89 \\
\hline 2002 & 17 & 304 & $3 \%$ & $-1.0 \%$ & 1.09 & 0.74 & 10 & $-0.5 \%$ & 1.01 & 0.71 \\
\hline 2003 & 21 & 255 & $16 \%$ & $-0.4 \%$ & 1.74 & 1.08 & 12 & $5.7 \%$ & 1.79 & 1.16 \\
\hline 2004 & 40 & 265 & $24 \%$ & $1.5 \%$ & 1.65 & 0.96 & 18 & $1.6 \%$ & 1.35 & 0.79 \\
\hline 2005 & 65 & 284 & $22 \%$ & $3.2 \%$ & 1.55 & 0.95 & 41 & $3.8 \%$ & 1.68 & 1.07 \\
\hline 2006 & 79 & 345 & $28 \%$ & $2.8 \%$ & 1.50 & 0.81 & 42 & $2.4 \%$ & 1.54 & 0.84 \\
\hline 2007 & 76 & 321 & $34 \%$ & $9.8 \%$ & 2.12 & 1.08 & 45 & $12.1 \%$ & 2.10 & 1.09 \\
\hline 2008 & 61 & 312 & $40 \%$ & $9.7 \%$ & 2.26 & 1.09 & 37 & $13.1 \%$ & 2.61 & 1.23 \\
\hline 2009 & 27 & 415 & $46 \%$ & $17.8 \%$ & 2.91 & 1.38 & 19 & $15.2 \%$ & 2.48 & 1.20 \\
\hline 2010 & 32 & 336 & $59 \%$ & $16.7 \%$ & 2.35 & 1.22 & 23 & $14.3 \%$ & 2.28 & 1.15 \\
\hline 2011 & 44 & 275 & $72 \%$ & $16.7 \%$ & 2.62 & 1.41 & 24 & $18.6 \%$ & 2.94 & 1.52 \\
\hline 2012 & 62 & 317 & $75 \%$ & $17.2 \%$ & 2.19 & 1.31 & 38 & $17.8 \%$ & 2.29 & 1.37 \\
\hline 2013 & 51 & 250 & $81 \%$ & $19.9 \%$ & 2.09 & 1.38 & 28 & $19.2 \%$ & 1.96 & 1.29 \\
\hline 2014 & 70 & 288 & $88 \%$ & $22.3 \%$ & 1.69 & 1.20 & 45 & $28.8 \%$ & 1.77 & 1.26 \\
\hline $\begin{array}{l}\text { Overall } \\
\text { Sample }\end{array}$ & 1,329 & 247 & $24 \%$ & $14.8 \%$ & 2.11 & 1.22 & 726 & $17.8 \%$ & 2.28 & 1.34 \\
\hline
\end{tabular}




\section{Table 2: Performance by Quartile}

This table presents average performance by quartile. The sample is split into buyout funds (Panel A) and venture capital funds (Panel B). For each asset class, funds are assigned into quartiles separately for IRR, MOIC and PME, and the (un-weighted) average performance of the funds in each quartile is presented. The sample is then further split according to whether the vintage year of the fund was up to (and including) 2000, or after 2000. Performance is as of June 2019. See Table 1 for further information on the data sample.

\section{Panel A: Buyout Funds}

\begin{tabular}{|c|c|c|c|c|}
\hline & $\begin{array}{c}\text { Average } \\
\text { IRR }\end{array}$ & $\begin{array}{c}\text { Average } \\
\text { MOIC }\end{array}$ & $\begin{array}{c}\text { Average } \\
\text { PME }\end{array}$ & $\mathrm{N}$ \\
\hline & \multicolumn{4}{|c|}{ Whole sample } \\
\hline Quartile 1 & $30.6 \%$ & 2.74 & 1.81 & 214 \\
\hline Quartile 2 & $17.5 \%$ & 1.98 & 1.30 & 225 \\
\hline Quartile 3 & $10.5 \%$ & 1.52 & 1.03 & 235 \\
\hline \multirow[t]{2}{*}{ Quartile 4} & $-1.4 \%$ & 1.00 & 0.68 & 219 \\
\hline & \multicolumn{4}{|c|}{ Pre-2001 Funds } \\
\hline Quartile 1 & $32.1 \%$ & 3.08 & 2.05 & 66 \\
\hline Quartile 2 & $17.2 \%$ & 2.22 & 1.40 & 73 \\
\hline Quartile 3 & $8.1 \%$ & 1.48 & 1.01 & 79 \\
\hline \multirow[t]{2}{*}{ Quartile 4} & $-5.1 \%$ & 0.87 & 0.61 & 69 \\
\hline & \multicolumn{4}{|c|}{ Post-2000 Funds } \\
\hline Quartile 1 & $29.9 \%$ & 2.58 & 1.70 & 148 \\
\hline Quartile 2 & $17.7 \%$ & 1.87 & 1.24 & 152 \\
\hline Quartile 3 & $11.7 \%$ & 1.54 & 1.04 & 156 \\
\hline Quartile 4 & $0.3 \%$ & 1.06 & 0.71 & 150 \\
\hline
\end{tabular}

\section{Panel B: Venture Capital funds}

\begin{tabular}{lrrrr}
\hline & $\begin{array}{c}\text { Average } \\
\text { IRR }\end{array}$ & $\begin{array}{c}\text { Average } \\
\text { MOIC }\end{array}$ & $\begin{array}{c}\text { Average } \\
\text { PME }\end{array}$ & $\mathrm{N}$ \\
\hline & \multicolumn{4}{c}{ Whole sample } \\
Quartile 1 & $45.3 \%$ & 4.53 & 2.60 & 318 \\
Quartile 2 & $17.2 \%$ & 2.00 & 1.17 & 341 \\
Quartile 3 & $5.8 \%$ & 1.31 & 0.76 & 344 \\
Quartile 4 & $-8.2 \%$ & 0.70 & 0.41 & 326 \\
& & & \\
Quartile 1 & $63.0 \%$ & 5.34 & 3.19 & 146 \\
Quartile 2 & $21.5 \%$ & 2.16 & 1.25 & 162 \\
Quartile 3 & $5.6 \%$ & 1.32 & 0.75 & 166 \\
Quartile 4 & $-9.0 \%$ & 0.69 & 0.38 & 150 \\
\cline { 2 - 5 } & & \multicolumn{3}{c}{ Pre-2001 Funds } \\
Quartile 1 & $30.0 \%$ & 3.84 & 2.11 \\
Quartile 2 & $13.3 \%$ & 1.85 & 1.09 & 179 \\
Quartile 3 & $6.0 \%$ & 1.30 & 0.78 & 178 \\
Quartile 4 & $-7.4 \%$ & 0.72 & 0.43 & 176 \\
\hline
\end{tabular}




\section{Table 3: Fund Persistence by Quartile Performance at Fund End}

This table shows the relationship between the performance, as measured by PME, of successive funds, according to their performance quartile. The sample is split according to buyout funds (Panel A) and venture capital funds (Panel B). Separately for each asset class and for each vintage year the funds are assigned to a quartile according to PME performance. Where the prior fund performance is available, the current fund quartile is matched to the previous fund quartile. Where the current fund was the first in the fund sequence for a given GP, the fund is assigned to the "First funds" category. In the remaining cases - where the previous fund performance is not available in our sample - the funds are allocated to the "NA, but not first fund" category. See Table 1 for further information on the data sample.

\section{Panel A: Buyout Funds}

\begin{tabular}{|c|c|c|c|c|c|c|c|c|c|}
\hline & & \multicolumn{4}{|c|}{ Current Fund Quartile } & \multirow[b]{2}{*}{$\mathrm{N}$} & \multicolumn{3}{|c|}{ Average Current Fund } \\
\hline & & 1 & 2 & 3 & 4 & & $\operatorname{IRR}(\%)$ & MOIC & PME \\
\hline \multicolumn{10}{|c|}{ Whole Sample } \\
\hline \multirow{8}{*}{$\begin{array}{l}\text { Previous Fund Quartile } \\
\text { at Fund End }\end{array}$} & 1 & $34.8 \%$ & $22.5 \%$ & $26.8 \%$ & $15.9 \%$ & & 16.9 & 1.92 & 1.30 \\
\hline & & 48 & 31 & 37 & 22 & 138 & & & \\
\hline & 2 & $20.6 \%$ & $27.9 \%$ & $30.1 \%$ & $21.3 \%$ & & 15.3 & 1.85 & 1.20 \\
\hline & & 28 & 38 & 41 & 29 & 136 & & & \\
\hline & 3 & $16.8 \%$ & $29.8 \%$ & $32.1 \%$ & $21.4 \%$ & & 13.0 & 1.68 & 1.14 \\
\hline & & 22 & 39 & 42 & 28 & 131 & & & \\
\hline & 4 & $15.2 \%$ & $20.3 \%$ & $25.3 \%$ & $39.2 \%$ & & 9.5 & 1.48 & 1.01 \\
\hline & & 12 & 16 & 20 & 31 & 79 & & & \\
\hline \multirow[t]{2}{*}{ NA, but not first fund } & & $24.4 \%$ & $27.3 \%$ & $23.9 \%$ & $24.4 \%$ & & 13.5 & 1.74 & 1.17 \\
\hline & & 50 & 56 & 49 & 50 & 205 & & & \\
\hline \multirow{2}{*}{ First funds } & & $26.5 \%$ & $22.1 \%$ & $22.5 \%$ & $28.9 \%$ & & 14.8 & 1.93 & 1.26 \\
\hline & & 54 & 45 & 46 & 59 & 204 & & & \\
\hline \multicolumn{10}{|c|}{ Pre-2001 Funds } \\
\hline \multirow{8}{*}{$\begin{array}{l}\text { Previous Fund Quartile } \\
\text { at Fund End }\end{array}$} & 1 & $40.7 \%$ & $18.5 \%$ & $22.2 \%$ & $18.5 \%$ & & 13.3 & 1.85 & 1.40 \\
\hline & & 11 & 5 & 6 & 5 & 27 & & & \\
\hline & 2 & $27.3 \%$ & $27.3 \%$ & $30.3 \%$ & $15.2 \%$ & & 13.8 & 2.09 & 1.26 \\
\hline & & 9 & 9 & 10 & 5 & 33 & & & \\
\hline & 3 & $19.0 \%$ & $21.4 \%$ & $33.3 \%$ & $26.2 \%$ & & 7.8 & 1.63 & 1.12 \\
\hline & & 8 & 9 & 14 & 11 & 42 & & & \\
\hline & 4 & $9.1 \%$ & $18.2 \%$ & $36.4 \%$ & $36.4 \%$ & & 5.0 & 1.33 & 0.97 \\
\hline & & 2 & 4 & 8 & 8 & 22 & & & \\
\hline \multirow[t]{2}{*}{ NA, but not first fund } & & $23.6 \%$ & $31.9 \%$ & $27.8 \%$ & $16.7 \%$ & & 13.9 & 1.86 & 1.26 \\
\hline & & 17 & 23 & 20 & 12 & 72 & & & \\
\hline \multirow[t]{2}{*}{ First funds } & & $20.9 \%$ & $25.3 \%$ & $23.1 \%$ & $30.8 \%$ & & 15.4 & 2.09 & 1.33 \\
\hline & & 19 & 23 & 21 & 28 & 91 & & & \\
\hline \multicolumn{10}{|c|}{ Post-2000 Funds } \\
\hline \multirow{8}{*}{$\begin{array}{l}\text { Previous Fund Quartile } \\
\text { at Fund End }\end{array}$} & 1 & $33.3 \%$ & $23.4 \%$ & $27.9 \%$ & $15.3 \%$ & & 17.8 & 1.93 & 1.27 \\
\hline & & 37 & 26 & 31 & 17 & 111 & & & \\
\hline & 2 & $18.4 \%$ & $28.2 \%$ & $30.1 \%$ & $23.3 \%$ & & 15.7 & 1.78 & 1.18 \\
\hline & & 19 & 29 & 31 & 24 & 103 & & & \\
\hline & 3 & $15.7 \%$ & $33.7 \%$ & $31.5 \%$ & $19.1 \%$ & & 15.5 & 1.71 & 1.15 \\
\hline & & 14 & 30 & 28 & 17 & 89 & & & \\
\hline & 4 & $17.5 \%$ & $21.1 \%$ & $21.1 \%$ & $40.4 \%$ & & 11.3 & 1.54 & 1.02 \\
\hline & & 10 & 12 & 12 & 23 & 57 & & & \\
\hline \multirow[t]{2}{*}{ NA, but not first fund } & & $24.8 \%$ & $24.8 \%$ & $21.8 \%$ & $28.6 \%$ & & 13.2 & 1.67 & 1.13 \\
\hline & & 33 & 33 & 29 & 38 & 133 & & & \\
\hline \multirow[t]{2}{*}{ First funds } & & $31.0 \%$ & $19.5 \%$ & $22.1 \%$ & $27.4 \%$ & & 14.3 & 1.80 & 1.21 \\
\hline & & 35 & 22 & 25 & 31 & 113 & & & \\
\hline
\end{tabular}


Table 3: Fund Persistence by Quartile Performance at Fund End (continued)

\section{Panel B: Venture Capital Funds}

\begin{tabular}{|c|c|c|c|c|c|c|c|c|c|}
\hline & & \multicolumn{4}{|c|}{ Current Fund Quartile } & \multirow[b]{2}{*}{$\mathrm{N}$} & \multicolumn{3}{|c|}{ Average Current Fund } \\
\hline & & 1 & 2 & 3 & 4 & & $\operatorname{IRR}(\%)$ & MOIC & PME \\
\hline \multicolumn{10}{|c|}{ Whole Sample } \\
\hline \multirow{7}{*}{$\begin{array}{l}\text { Previous Fund Quartile } \\
\text { at Fund End }\end{array}$} & 1 & $\begin{array}{c}44.7 \% \\
98\end{array}$ & $\begin{array}{c}24.2 \% \\
53\end{array}$ & $\begin{array}{c}18.7 \% \\
41\end{array}$ & $\begin{array}{c}12.3 \% \\
27\end{array}$ & 219 & 32.5 & 3.44 & 2.06 \\
\hline & 2 & $22.9 \%$ & $27.3 \%$ & $31.2 \%$ & $18.5 \%$ & & 18.2 & 2.15 & 1.24 \\
\hline & & 47 & 56 & 64 & 38 & 205 & & & \\
\hline & 3 & $16.8 \%$ & $33.7 \%$ & $29.3 \%$ & $20.1 \%$ & & 10.8 & 1.76 & 1.03 \\
\hline & & 31 & 62 & 54 & 37 & 184 & & & \\
\hline & 4 & $9.3 \%$ & $18.6 \%$ & $26.3 \%$ & $45.8 \%$ & & 0.8 & 1.16 & 0.67 \\
\hline & & 11 & 22 & 31 & 54 & 118 & & & \\
\hline \multirow[t]{2}{*}{ NA, but not first fund } & & $16.1 \%$ & $24.7 \%$ & $28.2 \%$ & $31.0 \%$ & & 7.6 & 1.70 & 0.93 \\
\hline & & 51 & 78 & 89 & 98 & 316 & & & \\
\hline \multirow[t]{2}{*}{ First funds } & & $27.9 \%$ & $24.4 \%$ & $22.6 \%$ & $25.1 \%$ & & 14.8 & 2.14 & 1.24 \\
\hline & & 80 & 70 & 65 & 72 & 287 & & & \\
\hline \multicolumn{10}{|c|}{ Pre-2001 Funds } \\
\hline \multirow{8}{*}{$\begin{array}{l}\text { Previous Fund Quartile } \\
\text { at Fund End }\end{array}$} & 1 & $44.9 \%$ & $20.2 \%$ & $19.1 \%$ & $15.7 \%$ & & 53.8 & 4.42 & 2.77 \\
\hline & & 40 & 18 & 17 & 14 & 89 & & & \\
\hline & 2 & $28.7 \%$ & $24.1 \%$ & $33.3 \%$ & $13.8 \%$ & & 24.4 & 2.65 & 1.55 \\
\hline & & 25 & 21 & 29 & 12 & 87 & & & \\
\hline & 3 & $18.1 \%$ & $28.9 \%$ & $31.3 \%$ & $21.7 \%$ & & 12.7 & 1.88 & 1.07 \\
\hline & & 15 & 24 & 26 & 18 & 83 & & & \\
\hline & 4 & $14.3 \%$ & $14.3 \%$ & $24.5 \%$ & $46.9 \%$ & & -0.2 & 1.10 & 0.66 \\
\hline & & 7 & 7 & 12 & 23 & 49 & & & \\
\hline \multirow[t]{2}{*}{ NA, but not first fund } & & $12.3 \%$ & $32.5 \%$ & $26.4 \%$ & $28.8 \%$ & & 10.1 & 1.76 & 0.96 \\
\hline & & 20 & 53 & 43 & 47 & 163 & & & \\
\hline \multirow[t]{2}{*}{ First funds } & & $25.5 \%$ & $25.5 \%$ & $25.5 \%$ & $23.5 \%$ & & 17.9 & 2.20 & 1.24 \\
\hline & & 39 & 39 & 39 & 36 & 153 & & & \\
\hline \multicolumn{10}{|c|}{ Post-2000 Funds } \\
\hline \multirow{8}{*}{$\begin{array}{l}\text { Previous Fund Quartile } \\
\text { at Fund End }\end{array}$} & 1 & $44.6 \%$ & $26.9 \%$ & $18.5 \%$ & $10.0 \%$ & & 18.0 & 2.77 & 1.57 \\
\hline & & 58 & 35 & 24 & 13 & 130 & & & \\
\hline & 2 & $18.6 \%$ & $29.7 \%$ & $29.7 \%$ & $22.0 \%$ & & 13.7 & 1.78 & 1.02 \\
\hline & & 22 & 35 & 35 & 26 & 118 & & & \\
\hline & 3 & $15.8 \%$ & $37.6 \%$ & $27.7 \%$ & $18.8 \%$ & & 9.4 & 1.66 & 0.99 \\
\hline & & 16 & 38 & 28 & 19 & 101 & & & \\
\hline & 4 & $5.8 \%$ & $21.7 \%$ & $27.5 \%$ & $44.9 \%$ & & 1.6 & 1.20 & 0.69 \\
\hline & & 4 & 15 & 19 & 31 & 69 & & & \\
\hline \multirow[t]{2}{*}{ NA, but not first fund } & & $20.3 \%$ & $16.3 \%$ & $30.1 \%$ & $33.3 \%$ & & 5.0 & 1.64 & 0.90 \\
\hline & & 31 & 25 & 46 & 51 & 153 & & & \\
\hline \multirow[t]{2}{*}{ First funds } & & $30.6 \%$ & $23.1 \%$ & $19.4 \%$ & $26.9 \%$ & & 11.2 & 2.06 & 1.23 \\
\hline & & 41 & 31 & 26 & 36 & 134 & & & \\
\hline
\end{tabular}




\section{Table 4: Fund Persistence by Quartile Performance at Fundraise}

This table shows the relationship between the performance, as measured by PME, of successive funds, according to their performance quartile. The sample is split according to buyout funds (Panel A) and venture capital funds (Panel B). Separately for each asset class and for each vintage year the funds are assigned to a quartile according to PME performance. Where the prior fund performance is available, the current fund quartile is matched to the previous fund quartile. Where the current fund was the first in the fund sequence for a given GP, the fund is assigned to the "First funds" category. In the remaining cases - where the previous fund performance is not available in our sample - the funds are allocated to the "NA, but not first fund" category. See Table 1 for further information on the data sample.

\section{Panel A: Buyout Funds}

\begin{tabular}{|c|c|c|c|c|c|c|c|c|c|}
\hline & & \multicolumn{4}{|c|}{ Current Fund Quartile } & \multirow[b]{2}{*}{$\mathrm{N}$} & \multicolumn{3}{|c|}{ Average Current Fund } \\
\hline & & 1 & 2 & 3 & 4 & & $\operatorname{IRR}(\%)$ & MOIC & PME \\
\hline \multicolumn{10}{|c|}{ Whole Sample } \\
\hline \multirow{8}{*}{$\begin{array}{l}\text { Previous Fund Quartile } \\
\text { at Fundraise }\end{array}$} & 1 & $26.6 \%$ & $23.1 \%$ & $26.6 \%$ & $23.8 \%$ & & 15.4 & 1.78 & 1.21 \\
\hline & & 38 & 33 & 38 & 34 & 143 & & & \\
\hline & 2 & $24.3 \%$ & $27.7 \%$ & $28.2 \%$ & $19.8 \%$ & & 14.4 & 1.77 & 1.22 \\
\hline & & 43 & 49 & 50 & 35 & 177 & & & \\
\hline & 3 & $14.5 \%$ & $25.5 \%$ & $34.5 \%$ & $25.5 \%$ & & 12.9 & 1.73 & 1.08 \\
\hline & & 16 & 28 & 38 & 28 & 110 & & & \\
\hline & 4 & $22.6 \%$ & $26.4 \%$ & $26.4 \%$ & $24.5 \%$ & & 12.8 & 1.76 & 1.17 \\
\hline & & 12 & 14 & 14 & 13 & 53 & & & \\
\hline \multirow[t]{2}{*}{ NA, but not first fund } & & $24.8 \%$ & $27.2 \%$ & $23.8 \%$ & $24.3 \%$ & & 13.5 & 1.74 & 1.18 \\
\hline & & 51 & 56 & 49 & 50 & 206 & & & \\
\hline \multirow[t]{2}{*}{ First funds } & & $26.5 \%$ & $22.1 \%$ & $22.5 \%$ & $28.9 \%$ & & 14.8 & 1.93 & 1.26 \\
\hline & & 54 & 45 & 46 & 59 & 204 & & & \\
\hline \multicolumn{10}{|c|}{ Pre-2001 Funds } \\
\hline \multirow{8}{*}{$\begin{array}{l}\text { Previous Fund Quartile } \\
\text { at Fundraise }\end{array}$} & 1 & $36.7 \%$ & $20.0 \%$ & $23.3 \%$ & $20.0 \%$ & & 12.8 & 1.73 & 1.28 \\
\hline & & 11 & 6 & 7 & 6 & 30 & & & \\
\hline & 2 & $28.6 \%$ & $26.5 \%$ & $26.5 \%$ & $18.4 \%$ & & 11.7 & 1.79 & 1.30 \\
\hline & & 14 & 13 & 13 & 9 & 49 & & & \\
\hline & 3 & $8.0 \%$ & $16.0 \%$ & $44.0 \%$ & $32.0 \%$ & & 5.7 & 1.78 & 0.93 \\
\hline & & 2 & 4 & 11 & 8 & 25 & & & \\
\hline & 4 & $15.0 \%$ & $20.0 \%$ & $35.0 \%$ & $30.0 \%$ & & 7.7 & 1.62 & 1.11 \\
\hline & & 3 & 4 & 7 & 6 & 20 & & & \\
\hline \multirow[t]{2}{*}{ NA, but not first fund } & & $23.6 \%$ & $31.9 \%$ & $27.8 \%$ & $16.7 \%$ & & 13.9 & 1.86 & 1.26 \\
\hline & & 17 & 23 & 20 & 12 & 72 & & & \\
\hline \multirow[t]{2}{*}{ First funds } & & $20.9 \%$ & $25.3 \%$ & $23.1 \%$ & $30.8 \%$ & & 15.4 & 2.09 & 1.33 \\
\hline & & 19 & 23 & 21 & 28 & 91 & & & \\
\hline \multicolumn{10}{|c|}{ Post-2000 Funds } \\
\hline \multirow{8}{*}{$\begin{array}{l}\text { Previous Fund Quartile } \\
\text { at Fundraise }\end{array}$} & 1 & $23.9 \%$ & $23.9 \%$ & $27.4 \%$ & $24.8 \%$ & & 16.0 & 1.79 & 1.19 \\
\hline & & 27 & 27 & 31 & 28 & 113 & & & \\
\hline & 2 & $22.7 \%$ & $28.1 \%$ & $28.9 \%$ & $20.3 \%$ & & 15.4 & 1.77 & 1.19 \\
\hline & & 29 & 36 & 37 & 26 & 128 & & & \\
\hline & 3 & $16.5 \%$ & $28.2 \%$ & $31.8 \%$ & $23.5 \%$ & & 15.0 & 1.72 & 1.12 \\
\hline & & 14 & 24 & 27 & 20 & 85 & & & \\
\hline & 4 & $27.3 \%$ & $30.3 \%$ & $21.2 \%$ & $21.2 \%$ & & 15.9 & 1.85 & 1.20 \\
\hline & & 9 & 10 & 7 & 7 & 33 & & & \\
\hline \multirow[t]{2}{*}{ NA, but not first fund } & & $25.4 \%$ & $24.6 \%$ & $21.6 \%$ & $28.4 \%$ & & 13.3 & 1.67 & 1.13 \\
\hline & & 34 & 33 & 29 & 38 & 134 & & & \\
\hline \multirow[t]{2}{*}{ First funds } & & $31.0 \%$ & $19.5 \%$ & $22.1 \%$ & $27.4 \%$ & & 14.3 & 1.80 & 1.21 \\
\hline & & 35 & 22 & 25 & 31 & 113 & & & \\
\hline
\end{tabular}


Table 4: Fund Persistence by Quartile Performance at Fundraise (continued)

\section{Panel B: Venture Capital Funds}

\begin{tabular}{|c|c|c|c|c|c|c|c|c|c|}
\hline & & \multicolumn{4}{|c|}{ Current Fund Quartile } & \multirow[b]{2}{*}{$\mathrm{N}$} & \multicolumn{3}{|c|}{ Average Current Fund } \\
\hline & & 1 & 2 & 3 & 4 & & $\operatorname{IRR}(\%)$ & MOIC & PME \\
\hline \multicolumn{10}{|c|}{ Whole Sample } \\
\hline \multirow{8}{*}{$\begin{array}{l}\text { Previous Fund Quartile } \\
\text { at Fundraise }\end{array}$} & 1 & $32.9 \%$ & $24.3 \%$ & $24.7 \%$ & $18.0 \%$ & & 26.3 & 2.85 & 1.70 \\
\hline & & 84 & 62 & 63 & 46 & 255 & & & \\
\hline & 2 & $26.4 \%$ & $31.6 \%$ & $23.4 \%$ & $18.6 \%$ & & 18.7 & 2.36 & 1.33 \\
\hline & & 61 & 73 & 54 & 43 & 231 & & & \\
\hline & 3 & $16.6 \%$ & $22.7 \%$ & $31.9 \%$ & $28.8 \%$ & & 8.9 & 1.65 & 0.99 \\
\hline & & 27 & 37 & 52 & 47 & 163 & & & \\
\hline & 4 & $19.5 \%$ & $27.3 \%$ & $27.3 \%$ & $26.0 \%$ & & 6.1 & 1.47 & 0.91 \\
\hline & & 15 & 21 & 21 & 20 & 77 & & & \\
\hline \multirow[t]{2}{*}{ NA, but not first fund } & & $16.1 \%$ & $24.7 \%$ & $28.2 \%$ & $31.0 \%$ & & 7.6 & 1.70 & 0.93 \\
\hline & & 51 & 78 & 89 & 98 & 316 & & & \\
\hline \multirow[t]{2}{*}{ First funds } & & $27.9 \%$ & $24.4 \%$ & $22.6 \%$ & $25.1 \%$ & & 14.8 & 2.14 & 1.24 \\
\hline & & 80 & 70 & 65 & 72 & 287 & & & \\
\hline \multicolumn{10}{|c|}{ Pre-2001 Funds } \\
\hline \multirow{8}{*}{$\begin{array}{l}\text { Previous Fund Quartile } \\
\text { at Fundraise }\end{array}$} & 1 & $37.4 \%$ & $25.3 \%$ & $21.2 \%$ & $16.2 \%$ & & 44.6 & 3.97 & 2.50 \\
\hline & & 37 & 25 & 21 & 16 & 99 & & & \\
\hline & 2 & $32.7 \%$ & $23.5 \%$ & $25.5 \%$ & $18.4 \%$ & & 27.7 & 2.80 & 1.58 \\
\hline & & 32 & 23 & 25 & 18 & 98 & & & \\
\hline & 3 & $11.8 \%$ & $21.1 \%$ & $35.5 \%$ & $31.6 \%$ & & 8.3 & 1.52 & 0.90 \\
\hline & & 9 & 16 & 27 & 24 & 76 & & & \\
\hline & 4 & $25.7 \%$ & $17.1 \%$ & $31.4 \%$ & $25.7 \%$ & & 5.4 & 1.45 & 0.91 \\
\hline & & 9 & 6 & 11 & 9 & 35 & & & \\
\hline \multirow[t]{2}{*}{ NA, but not first fund } & & $12.3 \%$ & $32.5 \%$ & $26.4 \%$ & $28.8 \%$ & & 10.1 & 1.76 & 0.96 \\
\hline & & 20 & 53 & 43 & 47 & 163 & & & \\
\hline \multirow[t]{2}{*}{ First funds } & & $25.5 \%$ & $25.5 \%$ & $25.5 \%$ & $23.5 \%$ & & 17.9 & 2.20 & 1.24 \\
\hline & & 39 & 39 & 39 & 36 & 153 & & & \\
\hline \multicolumn{10}{|c|}{ Post-2000 Funds } \\
\hline \multirow{8}{*}{$\begin{array}{l}\text { Previous Fund Quartile } \\
\text { at Fundraise }\end{array}$} & 1 & $30.1 \%$ & $23.7 \%$ & $26.9 \%$ & $19.2 \%$ & & 14.7 & 2.14 & 1.20 \\
\hline & & 47 & 37 & 42 & 30 & 156 & & & \\
\hline & 2 & $21.8 \%$ & $37.6 \%$ & $21.8 \%$ & $18.8 \%$ & & 12.2 & 2.04 & 1.15 \\
\hline & & 29 & 50 & 29 & 25 & 133 & & & \\
\hline & 3 & $20.7 \%$ & $24.1 \%$ & $28.7 \%$ & $26.4 \%$ & & 9.4 & 1.76 & 1.07 \\
\hline & & 18 & 21 & 25 & 23 & 87 & & & \\
\hline & 4 & $14.3 \%$ & $35.7 \%$ & $23.8 \%$ & $26.2 \%$ & & 6.6 & 1.49 & 0.91 \\
\hline & & 6 & 15 & 10 & 11 & 42 & & & \\
\hline \multirow[t]{2}{*}{ NA, but not first fund } & & $20.3 \%$ & $16.3 \%$ & $30.1 \%$ & $33.3 \%$ & & 5.0 & 1.64 & 0.90 \\
\hline & & 31 & 25 & 46 & 51 & 153 & & & \\
\hline \multirow[t]{2}{*}{ First funds } & & $30.6 \%$ & $23.1 \%$ & $19.4 \%$ & $26.9 \%$ & & 11.2 & 2.06 & 1.23 \\
\hline & & 41 & 31 & 26 & 36 & 134 & & & \\
\hline
\end{tabular}


Table 5: PME Quartile of Previous Fund From Fundraise to Fund End

This table shows the relationship between the performance, as measured by PME, of successive funds, according to their performance quartile. The sample is split according to buyout funds (Panel A) and venture capital funds (Panel B). Separately for each asset class and for each vintage year the funds are assigned to a quartile according to PME performance. Where the prior fund performance is available, the current fund quartile is matched to the previous fund quartile. Where the current fund was the first in the fund sequence for a given GP, the fund is assigned to the "First funds" category. In the remaining cases - where the previous fund performance is not available in our sample - the funds are allocated to the "NA, but not first fund" category. See Table 1 for further information on the data sample.

\section{Panel A: Buyout Funds}

\begin{tabular}{|c|c|c|c|c|c|c|}
\hline & & \multicolumn{4}{|c|}{ Previous Fund Final Quartile } & \multirow[b]{2}{*}{$\mathrm{N}$} \\
\hline & & 1 & 2 & 3 & 4 & \\
\hline \multicolumn{7}{|c|}{ Whole Sample } \\
\hline \multirow{8}{*}{$\begin{array}{l}\text { Previous Fund Quartile } \\
\text { at Fundraise }\end{array}$} & 1 & $56.6 \%$ & $25.9 \%$ & $10.5 \%$ & $7.0 \%$ & \multirow{3}{*}{143} \\
\hline & & 81 & 37 & 15 & 10 & \\
\hline & 2 & $24.3 \%$ & $36.2 \%$ & $27.7 \%$ & $11.9 \%$ & \\
\hline & & 43 & 64 & 49 & 21 & \multirow[t]{2}{*}{177} \\
\hline & 3 & $7.3 \%$ & $26.4 \%$ & $42.7 \%$ & $23.6 \%$ & \\
\hline & & 8 & 29 & 47 & 26 & \multirow[t]{2}{*}{110} \\
\hline & 4 & $11.3 \%$ & $11.3 \%$ & $37.7 \%$ & $39.6 \%$ & \\
\hline & & 6 & 6 & 20 & 21 & 53 \\
\hline \multicolumn{7}{|c|}{ Pre-2001 Funds } \\
\hline \multirow{8}{*}{$\begin{array}{l}\text { Previous Fund Quartile } \\
\text { at Fundraise }\end{array}$} & 1 & $33.3 \%$ & $43.3 \%$ & $23.3 \%$ & N.A. & \multirow{3}{*}{30} \\
\hline & & 10 & 13 & 7 & 0 & \\
\hline & 2 & $30.6 \%$ & $20.4 \%$ & $38.8 \%$ & $10.2 \%$ & \\
\hline & & 15 & 10 & 19 & 5 & \multirow[t]{2}{*}{49} \\
\hline & 3 & $4.0 \%$ & $28.0 \%$ & $32.0 \%$ & $36.0 \%$ & \\
\hline & & 1 & 7 & 8 & 9 & \multirow[t]{2}{*}{25} \\
\hline & 4 & $5.0 \%$ & $15.0 \%$ & $40.0 \%$ & $40.0 \%$ & \\
\hline & & 1 & 3 & 8 & 8 & 20 \\
\hline \multicolumn{7}{|c|}{ Post-2000 Funds } \\
\hline \multirow{8}{*}{$\begin{array}{l}\text { Previous Fund Quartile } \\
\text { at Fundraise }\end{array}$} & 1 & $62.8 \%$ & $21.2 \%$ & $7.1 \%$ & $8.8 \%$ & \multirow{3}{*}{113} \\
\hline & & 71 & 24 & 8 & 10 & \\
\hline & 2 & $21.9 \%$ & $42.2 \%$ & $23.4 \%$ & $12.5 \%$ & \\
\hline & & 28 & 54 & 30 & 16 & \multirow[t]{2}{*}{128} \\
\hline & 3 & $8.2 \%$ & $25.9 \%$ & $45.9 \%$ & $20.0 \%$ & \\
\hline & & 7 & 22 & 39 & 17 & \multirow[t]{2}{*}{85} \\
\hline & 4 & $15.2 \%$ & $9.1 \%$ & $36.4 \%$ & $39.4 \%$ & \\
\hline & & 5 & 3 & 12 & 13 & 33 \\
\hline
\end{tabular}


Table 5: PME Quartile of Previous Fund From Fundraise to Fund End (continued)

\section{Panel B: Venture Capital Funds}

\begin{tabular}{|c|c|c|c|c|c|c|}
\hline & & \multicolumn{4}{|c|}{ Previous Fund Final Quartile } & \multirow[b]{2}{*}{$\mathrm{N}$} \\
\hline & & 1 & 2 & 3 & 4 & \\
\hline \multicolumn{7}{|c|}{ Whole Sample } \\
\hline \multirow{8}{*}{$\begin{array}{l}\text { Previous Fund Quartile } \\
\text { at Fundraise }\end{array}$} & 1 & $48.6 \%$ & $29.0 \%$ & $13.3 \%$ & $9.0 \%$ & \multirow{3}{*}{255} \\
\hline & & 124 & 74 & 34 & 23 & \\
\hline & 2 & $26.4 \%$ & $35.1 \%$ & $27.7 \%$ & $10.8 \%$ & \\
\hline & & 61 & 81 & 64 & 25 & \multirow[t]{2}{*}{231} \\
\hline & 3 & $12.3 \%$ & $23.9 \%$ & $41.7 \%$ & $22.1 \%$ & \\
\hline & & 20 & 39 & 68 & 36 & \multirow[t]{2}{*}{163} \\
\hline & 4 & $18.2 \%$ & $14.3 \%$ & $23.4 \%$ & $44.2 \%$ & \\
\hline & & 14 & 11 & 18 & 34 & 77 \\
\hline \multicolumn{7}{|c|}{ Pre-2001 Funds } \\
\hline \multirow{8}{*}{$\begin{array}{l}\text { Previous Fund Quartile } \\
\text { at Fundraise }\end{array}$} & 1 & $49.5 \%$ & $31.3 \%$ & $11.1 \%$ & $8.1 \%$ & \multirow{3}{*}{99} \\
\hline & & 49 & 31 & 11 & 8 & \\
\hline & 2 & $25.5 \%$ & $37.8 \%$ & $28.6 \%$ & $8.2 \%$ & \\
\hline & & 25 & 37 & 28 & 8 & \multirow[t]{2}{*}{98} \\
\hline & 3 & $10.5 \%$ & $18.4 \%$ & $47.4 \%$ & $23.7 \%$ & \\
\hline & & 8 & 14 & 36 & 18 & \multirow[t]{2}{*}{76} \\
\hline & 4 & $20.0 \%$ & $14.3 \%$ & $22.9 \%$ & $42.9 \%$ & \\
\hline & & 7 & 5 & 8 & 15 & 35 \\
\hline \multicolumn{7}{|c|}{ Post-2000 Funds } \\
\hline \multirow{8}{*}{$\begin{array}{l}\text { Previous Fund Quartile } \\
\text { at Fundraise }\end{array}$} & 1 & $48.1 \%$ & $27.6 \%$ & $14.7 \%$ & $9.6 \%$ & \multirow{3}{*}{156} \\
\hline & & 75 & 43 & 23 & 15 & \\
\hline & 2 & $27.1 \%$ & $33.1 \%$ & $27.1 \%$ & $12.8 \%$ & \\
\hline & & 36 & 44 & 36 & 17 & \multirow[t]{2}{*}{133} \\
\hline & 3 & $13.8 \%$ & $28.7 \%$ & $36.8 \%$ & $20.7 \%$ & \\
\hline & & 12 & 25 & 32 & 18 & \multirow[t]{2}{*}{87} \\
\hline & 4 & $16.7 \%$ & $14.3 \%$ & $23.8 \%$ & $45.2 \%$ & \\
\hline & & 7 & 6 & 10 & 19 & 42 \\
\hline
\end{tabular}




\section{Table 6: Fund Persistence by Quartile of $2^{\text {nd }}$ Previous Fund at Fundraise}

This table shows the relationship between the performance, as measured by PME, of the current fund and second previous funds of the same GP, according to their performance quartile. The sample is split according to buyout funds (Panel A) and venture capital funds (Panel B). Separately for each asset class and for each vintage year the funds are assigned to a quartile according to PME performance. Where the $2^{\text {nd }}$ previous fund performance is available, the current fund quartile is matched to the $2^{\text {nd }}$ previous fund quartile. See Table 1 for further information on the data sample.

\section{Panel A: Buyout Funds}

\begin{tabular}{|c|c|c|c|c|c|c|c|c|c|}
\hline & & \multicolumn{4}{|c|}{ Current Fund Quartile } & \multirow[b]{2}{*}{$\mathrm{N}$} & \multicolumn{3}{|c|}{ Average Current Fund } \\
\hline & & 1 & 2 & 3 & 4 & & $\operatorname{IRR}(\%)$ & MOIC & PME \\
\hline \multicolumn{10}{|c|}{ Whole Sample } \\
\hline \multirow{8}{*}{$\begin{array}{l}\text { Second Previous Fund } \\
\text { Quartile at Fundraise }\end{array}$} & 1 & $18.4 \%$ & $27.2 \%$ & $29.1 \%$ & $25.2 \%$ & & 12.7 & 1.68 & 1.14 \\
\hline & & 19 & 28 & 30 & 26 & 103 & & & \\
\hline & 2 & $29.7 \%$ & $25.7 \%$ & $23.0 \%$ & $21.6 \%$ & & 16.1 & 1.84 & 1.22 \\
\hline & & 22 & 19 & 17 & 16 & 74 & & & \\
\hline & 3 & $27.9 \%$ & $25.0 \%$ & $33.8 \%$ & $13.2 \%$ & & 16.3 & 1.78 & 1.23 \\
\hline & & 19 & 17 & 23 & 9 & 68 & & & \\
\hline & 4 & $10.3 \%$ & $31.0 \%$ & $41.4 \%$ & $17.2 \%$ & & 13.4 & 1.68 & 1.13 \\
\hline & & 3 & 9 & 12 & 5 & 29 & & & \\
\hline \multicolumn{10}{|c|}{ Pre-2001 Funds } \\
\hline \multirow{8}{*}{$\begin{array}{l}\text { Second Previous Fund } \\
\text { Quartile at Fundraise }\end{array}$} & 1 & $26.3 \%$ & $31.6 \%$ & $31.6 \%$ & $10.5 \%$ & & 11.6 & 1.72 & 1.33 \\
\hline & & 5 & 6 & 6 & 2 & 19 & & & \\
\hline & 2 & $27.8 \%$ & $33.3 \%$ & $16.7 \%$ & $22.2 \%$ & & 16.4 & 1.98 & 1.34 \\
\hline & & 5 & 6 & 3 & 4 & 18 & & & \\
\hline & 3 & $21.1 \%$ & $21.1 \%$ & $42.1 \%$ & $15.8 \%$ & & 10.2 & 1.69 & 1.22 \\
\hline & & 4 & 4 & 8 & 3 & 19 & & & \\
\hline & 4 & $16.7 \%$ & $16.7 \%$ & $50.0 \%$ & $16.7 \%$ & & 10.0 & 1.66 & 1.20 \\
\hline & & 1 & 1 & 3 & 1 & 6 & & & \\
\hline \multicolumn{10}{|c|}{ Post-2000 Funds } \\
\hline \multirow{8}{*}{$\begin{array}{l}\text { Second Previous Fund } \\
\text { Quartile at Fundraise }\end{array}$} & 1 & $16.7 \%$ & $26.2 \%$ & $28.6 \%$ & $28.6 \%$ & & 13.0 & 1.67 & 1.10 \\
\hline & & 14 & 22 & 24 & 24 & 84 & & & \\
\hline & 2 & $30.4 \%$ & $23.2 \%$ & $25.0 \%$ & $21.4 \%$ & & 16.0 & 1.80 & 1.18 \\
\hline & & 17 & 13 & 14 & 12 & 56 & & & \\
\hline & 3 & $30.6 \%$ & $26.5 \%$ & $30.6 \%$ & $12.2 \%$ & & 18.7 & 1.82 & 1.23 \\
\hline & & 15 & 13 & 15 & 6 & 49 & & & \\
\hline & 4 & $8.7 \%$ & $34.8 \%$ & $39.1 \%$ & $17.4 \%$ & & 14.4 & 1.68 & 1.12 \\
\hline & & 2 & 8 & 9 & 4 & 23 & & & \\
\hline
\end{tabular}


Table 6: Fund Persistence by Quartile of $2^{\text {nd }}$ Previous Fund at Fundraise (continued)

\section{Panel B: Venture Capital Funds}

\begin{tabular}{|c|c|c|c|c|c|c|c|c|c|}
\hline & & \multicolumn{4}{|c|}{ Current Fund Quartile } & \multirow[b]{2}{*}{$\mathrm{N}$} & \multicolumn{3}{|c|}{ Average Current Fund } \\
\hline & & 1 & 2 & 3 & 4 & & $\operatorname{IRR}(\%)$ & MOIC & PME \\
\hline \multicolumn{10}{|c|}{ Whole Sample } \\
\hline \multirow{8}{*}{$\begin{array}{l}\text { Second Previous Fund } \\
\text { Quartile at Fundraise }\end{array}$} & 1 & $31.1 \%$ & $29.5 \%$ & $22.1 \%$ & $17.4 \%$ & & 24.9 & 2.90 & 1.75 \\
\hline & & 59 & 56 & 42 & 33 & 190 & & & \\
\hline & 2 & $19.3 \%$ & $31.1 \%$ & $31.9 \%$ & $17.6 \%$ & & 18.5 & 2.44 & 1.38 \\
\hline & & 23 & 37 & 38 & 21 & 119 & & & \\
\hline & 3 & $26.5 \%$ & $24.8 \%$ & $30.1 \%$ & $18.6 \%$ & & 16.0 & 2.07 & 1.28 \\
\hline & & 30 & 28 & 34 & 21 & 113 & & & \\
\hline & 4 & $20.0 \%$ & $17.5 \%$ & $32.5 \%$ & $30.0 \%$ & & 3.3 & 1.25 & 0.74 \\
\hline & & 8 & 7 & 13 & 12 & 40 & & & \\
\hline \multicolumn{10}{|c|}{ Pre-2001 Funds } \\
\hline \multirow{8}{*}{$\begin{array}{l}\text { Second Previous Fund } \\
\text { Quartile at Fundraise }\end{array}$} & 1 & $37.3 \%$ & $26.5 \%$ & $20.5 \%$ & $15.7 \%$ & & 38.0 & 3.81 & 2.36 \\
\hline & & 31 & 22 & 17 & 13 & 83 & & & \\
\hline & 2 & $24.0 \%$ & $28.0 \%$ & $30.0 \%$ & $18.0 \%$ & & 30.6 & 3.22 & 1.85 \\
\hline & & 12 & 14 & 15 & 9 & 50 & & & \\
\hline & 3 & $26.1 \%$ & $26.1 \%$ & $30.4 \%$ & $17.4 \%$ & & 23.5 & 2.32 & 1.44 \\
\hline & & 12 & 12 & 14 & 8 & 46 & & & \\
\hline & 4 & $18.2 \%$ & $18.2 \%$ & $45.5 \%$ & $18.2 \%$ & & 12.4 & 1.21 & 0.74 \\
\hline & & 2 & 2 & 5 & 2 & 11 & & & \\
\hline \multicolumn{10}{|c|}{ Post-2000 Funds } \\
\hline \multirow{8}{*}{$\begin{array}{l}\text { Second Previous Fund } \\
\text { Quartile at Fundraise }\end{array}$} & 1 & $26.2 \%$ & $31.8 \%$ & $23.4 \%$ & $18.7 \%$ & & 14.7 & 2.19 & 1.28 \\
\hline & & 28 & 34 & 25 & 20 & 107 & & & \\
\hline & 2 & $15.9 \%$ & $33.3 \%$ & $33.3 \%$ & $17.4 \%$ & & 9.8 & 1.87 & 1.05 \\
\hline & & 11 & 23 & 23 & 12 & 69 & & & \\
\hline & 3 & $26.9 \%$ & $23.9 \%$ & $29.9 \%$ & $19.4 \%$ & & 10.9 & 1.91 & 1.17 \\
\hline & & 18 & 16 & 20 & 13 & 67 & & & \\
\hline & 4 & $20.7 \%$ & $17.2 \%$ & $27.6 \%$ & $34.5 \%$ & & 4.0 & 1.26 & 0.74 \\
\hline & & 6 & 5 & 8 & 10 & 29 & & & \\
\hline
\end{tabular}


Table 7: Fund Persistence by Quartile Performance at Fundraise using IRR

This table shows the relationship between the performance of successive funds, according to their performance quartile. The sample is split according to buyout funds (Panel A) and venture capital funds (Panel B). Separately for each asset class and for each vintage year the funds are assigned to a quartile according to performance measured by IRR. Only funds for which the prior fund performance is available are included. For each period and performance measure the current fund quartile is matched to the previous fund quartile. See Table 1 for further information on the data sample.

Panel A: Buyout Funds

\begin{tabular}{|c|c|c|c|c|c|c|c|c|c|}
\hline & & \multicolumn{4}{|c|}{ Current Fund Quartile } & \multirow[b]{2}{*}{$\mathrm{N}$} & \multicolumn{3}{|c|}{ Average Current Fund } \\
\hline & & 1 & 2 & 3 & 4 & & $\operatorname{IRR}(\%)$ & MOIC & PME \\
\hline \multicolumn{10}{|c|}{ Whole Sample } \\
\hline \multirow{4}{*}{$\begin{array}{l}\text { Previous Fund Quartile } \\
\text { at Fundraise }\end{array}$} & 1 & $22.0 \%$ & $30.2 \%$ & $23.3 \%$ & $24.5 \%$ & 159 & 14.5 & 1.75 & 1.21 \\
\hline & 2 & $27.5 \%$ & $24.0 \%$ & $26.3 \%$ & $22.2 \%$ & 167 & 15.7 & 1.79 & 1.21 \\
\hline & 3 & $17.6 \%$ & $24.5 \%$ & $28.4 \%$ & $29.4 \%$ & 102 & 12.0 & 1.76 & 1.08 \\
\hline & 4 & $24.1 \%$ & $27.8 \%$ & $29.6 \%$ & $18.5 \%$ & 54 & 13.0 & 1.75 & 1.17 \\
\hline NA, but not first fund & & $23.2 \%$ & $26.6 \%$ & $27.1 \%$ & $23.2 \%$ & 207 & 13.4 & 1.73 & 1.17 \\
\hline First funds & & $26.0 \%$ & $21.1 \%$ & $26.0 \%$ & $27.0 \%$ & 204 & 14.8 & 1.93 & 1.26 \\
\hline \multicolumn{10}{|c|}{ Pre-2001 Funds } \\
\hline \multirow{4}{*}{$\begin{array}{l}\text { Previous Fund Quartile } \\
\text { at Fundraise }\end{array}$} & 1 & $25.0 \%$ & $31.3 \%$ & $18.8 \%$ & $25.0 \%$ & 32 & 10.8 & 1.69 & 1.32 \\
\hline & 2 & $28.9 \%$ & $26.7 \%$ & $22.2 \%$ & $22.2 \%$ & 45 & 12.3 & 1.71 & 1.22 \\
\hline & 3 & $22.2 \%$ & $7.4 \%$ & $33.3 \%$ & $37.0 \%$ & 27 & 7.9 & 1.99 & 1.07 \\
\hline & 4 & $15.0 \%$ & $25.0 \%$ & $40.0 \%$ & $20.0 \%$ & 20 & 7.0 & 1.57 & 1.08 \\
\hline NA, but not first fund & & $23.6 \%$ & $29.2 \%$ & $29.2 \%$ & $18.1 \%$ & 72 & 13.9 & 1.86 & 1.26 \\
\hline First funds & & $19.8 \%$ & $26.4 \%$ & $27.5 \%$ & $26.4 \%$ & 91 & 15.4 & 2.09 & 1.33 \\
\hline \multicolumn{10}{|c|}{ Post-2000 Funds } \\
\hline \multirow{4}{*}{$\begin{array}{l}\text { Previous Fund Quartile } \\
\text { at Fundraise }\end{array}$} & 1 & $21.3 \%$ & $29.9 \%$ & $24.4 \%$ & $24.4 \%$ & 127 & 15.4 & 1.76 & 1.18 \\
\hline & 2 & $27.0 \%$ & $23.0 \%$ & $27.9 \%$ & $22.1 \%$ & 122 & 16.9 & 1.82 & 1.21 \\
\hline & 3 & $16.0 \%$ & $30.7 \%$ & $26.7 \%$ & $26.7 \%$ & 75 & 13.6 & 1.68 & 1.09 \\
\hline & 4 & $29.4 \%$ & $29.4 \%$ & $23.5 \%$ & $17.6 \%$ & 34 & 16.4 & 1.85 & 1.22 \\
\hline NA, but not first fund & & $23.0 \%$ & $25.2 \%$ & $25.9 \%$ & $25.9 \%$ & 135 & 13.2 & 1.66 & 1.13 \\
\hline First funds & & $31.0 \%$ & $16.8 \%$ & $24.8 \%$ & $27.4 \%$ & 113 & 14.3 & 1.80 & 1.21 \\
\hline
\end{tabular}


Table 7: Fund Persistence by Quartile Performance at Fundraise using IRR (continued)

\section{Panel B: Venture Capital Funds}

\begin{tabular}{|c|c|c|c|c|c|c|c|c|c|}
\hline & & \multicolumn{4}{|c|}{ Current Fund Quartile } & \multirow[b]{2}{*}{$\mathrm{N}$} & \multicolumn{3}{|c|}{ Average Current Fund } \\
\hline & & 1 & 2 & 3 & 4 & & $\operatorname{IRR}(\%)$ & MOIC & PME \\
\hline \multicolumn{10}{|c|}{ Whole Sample } \\
\hline \multirow{4}{*}{$\begin{array}{l}\text { Previous Fund Quartile } \\
\text { at Fundraise }\end{array}$} & 1 & $31.8 \%$ & $26.5 \%$ & $23.9 \%$ & $17.8 \%$ & 264 & 26.4 & 2.85 & 1.71 \\
\hline & 2 & $26.6 \%$ & $32.3 \%$ & $20.5 \%$ & $20.5 \%$ & 229 & 19.9 & 2.41 & 1.35 \\
\hline & 3 & $10.7 \%$ & $23.3 \%$ & $41.3 \%$ & $24.7 \%$ & 150 & 5.7 & 1.46 & 0.89 \\
\hline & 4 & $24.1 \%$ & $26.5 \%$ & $20.5 \%$ & $28.9 \%$ & 83 & 7.2 & 1.58 & 0.95 \\
\hline NA, but not first fund & & $17.1 \%$ & $22.8 \%$ & $28.2 \%$ & $31.6 \%$ & 316 & 7.6 & 1.70 & 0.93 \\
\hline First funds & & $29.3 \%$ & $22.3 \%$ & $23.3 \%$ & $24.4 \%$ & 287 & 14.8 & 2.14 & 1.24 \\
\hline \multicolumn{10}{|c|}{ Pre-2001 Funds } \\
\hline \multirow{4}{*}{$\begin{array}{l}\text { Previous Fund Quartile } \\
\text { at Fundraise }\end{array}$} & 1 & $39.6 \%$ & $29.2 \%$ & $19.8 \%$ & $11.5 \%$ & 96 & 47.2 & 4.16 & 2.63 \\
\hline & 2 & $27.6 \%$ & $24.8 \%$ & $23.8 \%$ & $23.8 \%$ & 105 & 28.1 & 2.73 & 1.53 \\
\hline & 3 & $4.5 \%$ & $20.9 \%$ & $43.3 \%$ & $31.3 \%$ & 67 & 1.9 & 1.21 & 0.73 \\
\hline & 4 & $30.0 \%$ & $22.5 \%$ & $22.5 \%$ & $25.0 \%$ & 40 & 8.5 & 1.67 & 0.99 \\
\hline NA, but not first fund & & $14.7 \%$ & $28.8 \%$ & $25.8 \%$ & $30.7 \%$ & 163 & 10.1 & 1.76 & 0.96 \\
\hline First funds & & $27.5 \%$ & $23.5 \%$ & $27.5 \%$ & $21.6 \%$ & 153 & 17.9 & 2.20 & 1.24 \\
\hline \multicolumn{10}{|c|}{ Post-2000 Funds } \\
\hline \multirow{4}{*}{$\begin{array}{l}\text { Previous Fund Quartile } \\
\text { at Fundraise }\end{array}$} & 1 & $27.4 \%$ & $25.0 \%$ & $26.2 \%$ & $21.4 \%$ & 168 & 14.5 & 2.10 & 1.18 \\
\hline & 2 & $25.8 \%$ & $38.7 \%$ & $17.7 \%$ & $17.7 \%$ & 124 & 12.9 & 2.15 & 1.20 \\
\hline & 3 & $15.7 \%$ & $25.3 \%$ & $39.8 \%$ & $19.3 \%$ & 83 & 8.7 & 1.66 & 1.02 \\
\hline & 4 & $18.6 \%$ & $30.2 \%$ & $18.6 \%$ & $32.6 \%$ & 43 & 5.9 & 1.49 & 0.91 \\
\hline NA, but not first fund & & $24.8 \%$ & $27.2 \%$ & $23.8 \%$ & $24.3 \%$ & 153 & 5.0 & 1.64 & 0.90 \\
\hline First funds & & $26.5 \%$ & $22.1 \%$ & $22.5 \%$ & $28.9 \%$ & 134 & 11.2 & 2.06 & 1.23 \\
\hline
\end{tabular}




\section{Table 8: Fund Persistence by Quartile Performance at Fundraise using MOIC}

This table shows the relationship between the performance of successive funds, according to their performance quartile. The sample is split according to buyout funds (Panel A) and venture capital funds (Panel B). Separately for each asset class and for each vintage year the funds are assigned to a quartile according to performance measured by MOIC. Only funds for which the prior fund performance is available are included. For each period and performance measure the current fund quartile is matched to the previous fund quartile. See Table 1 for further information on the data sample.

\section{Panel A: Buyout Funds}

\begin{tabular}{|c|c|c|c|c|c|c|c|c|c|}
\hline & & \multicolumn{4}{|c|}{ Current Fund Quartile } & \multirow[b]{2}{*}{$\mathrm{N}$} & \multicolumn{3}{|c|}{ Average Current Fund } \\
\hline & & 1 & 2 & 3 & 4 & & IRR (\%) & MOIC & PME \\
\hline \multicolumn{10}{|c|}{ Whole Sample } \\
\hline \multirow{4}{*}{$\begin{array}{l}\text { Previous Fund Quartile } \\
\text { at Fundraise }\end{array}$} & 1 & $25.5 \%$ & $22.7 \%$ & $24.8 \%$ & $27.0 \%$ & 141 & 14.3 & 1.75 & 1.20 \\
\hline & 2 & $22.9 \%$ & $28.8 \%$ & $27.6 \%$ & $20.6 \%$ & 170 & 15.0 & 1.78 & 1.20 \\
\hline & 3 & $23.5 \%$ & $26.9 \%$ & $26.1 \%$ & $23.5 \%$ & 119 & 13.6 & 1.79 & 1.14 \\
\hline & 4 & $18.9 \%$ & $30.2 \%$ & $26.4 \%$ & $24.5 \%$ & 53 & 12.5 & 1.70 & 1.15 \\
\hline NA, but not first fund & & $22.8 \%$ & $26.7 \%$ & $26.2 \%$ & $24.3 \%$ & 206 & 13.5 & 1.74 & 1.18 \\
\hline First funds & & $24.5 \%$ & $21.6 \%$ & $26.5 \%$ & $27.5 \%$ & 204 & 14.8 & 1.93 & 1.26 \\
\hline \multicolumn{10}{|c|}{ Pre-2001 Funds } \\
\hline \multirow{4}{*}{$\begin{array}{l}\text { Previous Fund Quartile } \\
\text { at Fundraise }\end{array}$} & 1 & $25.0 \%$ & $28.6 \%$ & $17.9 \%$ & $28.6 \%$ & 28 & 10.7 & 1.66 & 1.27 \\
\hline & 2 & $26.7 \%$ & $35.6 \%$ & $17.8 \%$ & $20.0 \%$ & 45 & 12.0 & 1.73 & 1.22 \\
\hline & 3 & $27.3 \%$ & $21.2 \%$ & $24.2 \%$ & $27.3 \%$ & 33 & 9.4 & 2.00 & 1.17 \\
\hline & 4 & $11.1 \%$ & $22.2 \%$ & $38.9 \%$ & $27.8 \%$ & 18 & 5.6 & 1.43 & 1.04 \\
\hline NA, but not first fund & & $26.4 \%$ & $23.6 \%$ & $33.3 \%$ & $16.7 \%$ & 72 & 13.9 & 1.86 & 1.26 \\
\hline First funds & & $17.6 \%$ & $24.2 \%$ & $28.6 \%$ & $29.7 \%$ & 91 & 15.4 & 2.09 & 1.33 \\
\hline \multicolumn{10}{|c|}{ Post-2000 Funds } \\
\hline \multirow{4}{*}{$\begin{array}{l}\text { Previous Fund Quartile } \\
\text { at Fundraise }\end{array}$} & 1 & $25.7 \%$ & $21.2 \%$ & $26.5 \%$ & $26.5 \%$ & 113 & 15.2 & 1.77 & 1.18 \\
\hline & 2 & $21.6 \%$ & $26.4 \%$ & $31.2 \%$ & $20.8 \%$ & 125 & 16.0 & 1.79 & 1.19 \\
\hline & 3 & $22.1 \%$ & $29.1 \%$ & $26.7 \%$ & $22.1 \%$ & 86 & 15.2 & 1.71 & 1.12 \\
\hline & 4 & $22.9 \%$ & $34.3 \%$ & $20.0 \%$ & $22.9 \%$ & 35 & 16.1 & 1.84 & 1.21 \\
\hline NA, but not first fund & & $20.9 \%$ & $28.4 \%$ & $22.4 \%$ & $28.4 \%$ & 135 & 13.2 & 1.66 & 1.13 \\
\hline First funds & & $30.1 \%$ & $19.5 \%$ & $24.8 \%$ & $25.7 \%$ & 113 & 14.3 & 1.80 & 1.21 \\
\hline
\end{tabular}


Table 8: Fund Persistence by Quartile Performance at Fundraise using MOIC (continued)

Panel B: Venture Capital Funds

\begin{tabular}{|c|c|c|c|c|c|c|c|c|c|}
\hline & & \multicolumn{4}{|c|}{ Current Fund Quartile } & \multirow[b]{2}{*}{$\mathrm{N}$} & \multicolumn{3}{|c|}{ Average Current Fund } \\
\hline & & 1 & 2 & 3 & 4 & & $\operatorname{IRR}(\%)$ & MOIC & PME \\
\hline \multicolumn{10}{|c|}{ Whole Sample } \\
\hline \multirow{4}{*}{$\begin{array}{l}\text { Previous Fund Quartile } \\
\text { at Fundraise }\end{array}$} & 1 & $33.7 \%$ & $23.4 \%$ & $26.1 \%$ & $16.9 \%$ & 261 & 26.3 & 2.85 & 1.71 \\
\hline & 2 & $26.3 \%$ & $32.6 \%$ & $21.0 \%$ & $20.1 \%$ & 224 & 18.9 & 2.42 & 1.35 \\
\hline & 3 & $10.8 \%$ & $27.8 \%$ & $34.2 \%$ & $27.2 \%$ & 158 & 7.1 & 1.40 & 0.86 \\
\hline & 4 & $22.9 \%$ & $27.7 \%$ & $25.3 \%$ & $24.1 \%$ & 83 & 8.7 & 1.78 & 1.09 \\
\hline NA, but not first fund & & $18.7 \%$ & $22.2 \%$ & $26.9 \%$ & $32.3 \%$ & 316 & 7.6 & 1.70 & 0.93 \\
\hline First funds & & $27.2 \%$ & $23.0 \%$ & $25.1 \%$ & $24.7 \%$ & 287 & 14.8 & 2.14 & 1.24 \\
\hline \multicolumn{10}{|c|}{ Pre-2001 Funds } \\
\hline \multirow{4}{*}{$\begin{array}{l}\text { Previous Fund Quartile } \\
\text { at Fundraise }\end{array}$} & 1 & $42.3 \%$ & $17.5 \%$ & $26.8 \%$ & $13.4 \%$ & 97 & 45.6 & 4.07 & 2.55 \\
\hline & 2 & $32.3 \%$ & $28.1 \%$ & $20.8 \%$ & $18.8 \%$ & 96 & 28.5 & 2.89 & 1.62 \\
\hline & 3 & $5.3 \%$ & $25.3 \%$ & $32.0 \%$ & $37.3 \%$ & 75 & 5.5 & 1.22 & 0.78 \\
\hline & 4 & $27.5 \%$ & $25.0 \%$ & $25.0 \%$ & $22.5 \%$ & 40 & 9.4 & 1.74 & 1.02 \\
\hline NA, but not first fund & & $14.7 \%$ & $30.1 \%$ & $25.2 \%$ & $30.1 \%$ & 163 & 10.1 & 1.76 & 0.96 \\
\hline First funds & & $24.2 \%$ & $24.8 \%$ & $28.8 \%$ & $22.2 \%$ & 153 & 17.9 & 2.20 & 1.24 \\
\hline \multicolumn{10}{|c|}{ Post-2000 Funds } \\
\hline \multirow{4}{*}{$\begin{array}{l}\text { Previous Fund Quartile } \\
\text { at Fundraise }\end{array}$} & 1 & $28.7 \%$ & $26.8 \%$ & $25.6 \%$ & $18.9 \%$ & 164 & 14.9 & 2.13 & 1.21 \\
\hline & 2 & $21.9 \%$ & $35.9 \%$ & $21.1 \%$ & $21.1 \%$ & 128 & 11.8 & 2.06 & 1.15 \\
\hline & 3 & $15.7 \%$ & $30.1 \%$ & $36.1 \%$ & $18.1 \%$ & 83 & 8.6 & 1.56 & 0.93 \\
\hline & 4 & $18.6 \%$ & $30.2 \%$ & $25.6 \%$ & $25.6 \%$ & 43 & 8.0 & 1.81 & 1.16 \\
\hline NA, but not first fund & & $22.9 \%$ & $13.7 \%$ & $28.8 \%$ & $34.6 \%$ & 153 & 5.0 & 1.64 & 0.90 \\
\hline First funds & & $30.6 \%$ & $20.9 \%$ & $20.9 \%$ & $27.6 \%$ & 134 & 11.2 & 2.06 & 1.23 \\
\hline
\end{tabular}




\section{Table 9: Fund Persistence Regressions}

This table shows regressions of current fund performance, as measured by (log) PME, on previous fund performance. Previous Fund PME is measured at the time of fundraising. 2nd Previous Fund PME is the performance of the fund measured at the time fundraising. Dummies are included to capture if the current fund is over $50 \%$ and over $100 \%$ larger than the previous fund. Secondary fund style dummies are included for funds that not part of the main fund sequence for the GP. All PMEs are measured relative to the S\&P 500. Vintage year dummies are included for the current fund. Only funds for which a previous fund exists in our sample are included. See Table 1 for further information on the data sample. *, ** and *** denote that the coefficient is significantly different from zero, respectively, at the $10 \%, 5 \%$ and $1 \%$ level.

\begin{tabular}{|c|c|c|c|c|c|c|c|c|}
\hline \multicolumn{9}{|c|}{ Panel A: Whole sample } \\
\hline & \multicolumn{4}{|c|}{ Buyout Funds } & \multicolumn{4}{|c|}{ Venture Capital Funds } \\
\hline (Log) Previous Fund PME & $\begin{array}{c}0.043 \\
{[0.075]}\end{array}$ & $\begin{array}{c}0.004 \\
{[0.072]}\end{array}$ & & & $\begin{array}{c}0.329 * * * \\
{[0.079]}\end{array}$ & $\begin{array}{c}0.339 * * * \\
{[0.08]}\end{array}$ & & \\
\hline (Log) 2nd Previous Fund PME & & & $\begin{array}{c}-0.004 \\
{[0.069]}\end{array}$ & $\begin{array}{c}-0.048 \\
{[0.071]}\end{array}$ & & & $\begin{array}{c}0.202 * * * \\
{[0.058]}\end{array}$ & $\begin{array}{c}0.217 * * * \\
{[0.060]}\end{array}$ \\
\hline Fund size increases $>50 \%$ & & $\begin{array}{c}0.022 \\
{[0.046]}\end{array}$ & & $\begin{array}{c}-0.082 \\
{[0.073]}\end{array}$ & & $\begin{array}{c}-0.048 \\
{[0.071]}\end{array}$ & & $\begin{array}{c}-0.092 \\
{[0.105]}\end{array}$ \\
\hline Fund size increases $>100 \%$ & & $\begin{array}{c}0.061 \\
{[0.049]}\end{array}$ & & $\begin{array}{l}0.123^{*} \\
{[0.064]}\end{array}$ & & $\begin{array}{c}-0.078 \\
{[0.084]}\end{array}$ & & $\begin{array}{c}-0.045 \\
{[0.110]}\end{array}$ \\
\hline Secondary fund style & & $\begin{array}{c}-0.164 * * \\
{[0.082]}\end{array}$ & & $\begin{array}{c}-0.244 * * \\
{[0.105]}\end{array}$ & & $\begin{array}{c}0.221 \\
{[0.149]}\end{array}$ & & $\begin{array}{c}0.108 \\
{[0.316]}\end{array}$ \\
\hline Vintage Year FE & $\mathrm{Y}$ & $\mathrm{Y}$ & $\mathrm{Y}$ & $\mathrm{Y}$ & $\mathrm{Y}$ & $\mathrm{Y}$ & $\mathrm{Y}$ & $\mathrm{Y}$ \\
\hline $\mathrm{N}$ & 483 & 483 & 274 & 274 & 726 & 726 & 462 & 462 \\
\hline $\mathrm{R} 2$ & 0.04 & 0.05 & 0.15 & 0.19 & 0.26 & 0.26 & 0.29 & 0.29 \\
\hline \multicolumn{9}{|c|}{ Panel B: Pre-2001 Funds } \\
\hline & \multicolumn{4}{|c|}{ Buyout Funds } & \multicolumn{4}{|c|}{ Venture Capital Funds } \\
\hline (Log) Previous Fund PME & $\begin{array}{c}-0.156 \\
{[0.132]}\end{array}$ & $\begin{array}{l}-0.298^{*} \\
{[0.151]}\end{array}$ & & & $\begin{array}{c}0.341^{* * * *} \\
{[0.106]}\end{array}$ & $\begin{array}{c}0.356^{* * * *} \\
{[0.105]}\end{array}$ & & \\
\hline (Log) 2nd Previous Fund PME & & & $\begin{array}{c}0.180 \\
{[0.173]}\end{array}$ & $\begin{array}{l}0.327 * * \\
{[0.157]}\end{array}$ & & & $\begin{array}{c}0.274 * * * \\
{[0.092]}\end{array}$ & $\begin{array}{c}0.280 * * * \\
{[0.092]}\end{array}$ \\
\hline Fund size increases $>50 \%$ & & $\begin{array}{c}0.044 \\
{[0.138]}\end{array}$ & & $\begin{array}{c}-1.040 * * * \\
{[0.273]}\end{array}$ & & $\begin{array}{l}-0.263^{*} \\
{[0.110]}\end{array}$ & & $\begin{array}{c}0.285 \\
{[0.218]}\end{array}$ \\
\hline Fund size increases $>100 \%$ & & $\begin{array}{c}-0.041 \\
{[0.111]}\end{array}$ & & $\begin{array}{c}1.267 * * * \\
{[0.232]}\end{array}$ & & $\begin{array}{c}-0.219 * \\
{[0.112]}\end{array}$ & & $\begin{array}{c}-0.366 * * \\
{[0.185]}\end{array}$ \\
\hline Secondary fund style & & $\begin{array}{c}-0.451 * * \\
{[0.177]}\end{array}$ & & $\begin{array}{c}-0.011 \\
{[0.198]}\end{array}$ & & $\begin{array}{c}0.324 \\
{[0.343]}\end{array}$ & & $\begin{array}{c}-0.088 \\
{[0.565]}\end{array}$ \\
\hline Vintage Year FE & $\mathrm{Y}$ & $\mathrm{Y}$ & $\mathrm{Y}$ & $\mathrm{Y}$ & $\mathrm{Y}$ & $\mathrm{Y}$ & $\mathrm{Y}$ & $\mathrm{Y}$ \\
\hline $\mathrm{N}$ & 124 & 124 & 62 & 62 & 308 & 308 & 190 & 190 \\
\hline $\mathrm{R} 2$ & 0.13 & 0.18 & 0.25 & 0.51 & 0.4 & 0.44 & 0.44 & 0.46 \\
\hline \multicolumn{9}{|c|}{ Panel C: Post-2000 Funds } \\
\hline & \multicolumn{4}{|c|}{ Buyout Funds } & \multicolumn{4}{|c|}{ Venture Capital Funds } \\
\hline (Log) Previous Fund PME & $\begin{array}{c}0.194 * * \\
{[0.082]}\end{array}$ & $\begin{array}{c}0.173 * * \\
{[0.083]}\end{array}$ & & & $\begin{array}{l}0.306^{* * *} \\
{[0.127]}\end{array}$ & $\begin{array}{c}0.248^{*} \\
{[0.130]}\end{array}$ & & \\
\hline (Log) 2nd Previous Fund PME & & & $\begin{array}{c}-0.072 \\
{[0.074]}\end{array}$ & $\begin{array}{c}-0.107 \\
{[0.079]}\end{array}$ & & & $\begin{array}{c}0.125 \\
{[0.076]}\end{array}$ & $\begin{array}{c}0.152^{*} \\
{[0.079]}\end{array}$ \\
\hline Fund size increases $>50 \%$ & & $\begin{array}{c}0.005 \\
{[0.045]}\end{array}$ & & $\begin{array}{c}-0.003 \\
{[0.070]}\end{array}$ & & $\begin{array}{c}0.068 \\
{[0.095]}\end{array}$ & & $\begin{array}{c}-0.287 * * \\
{[0.117]}\end{array}$ \\
\hline Fund size increases $>100 \%$ & & $\begin{array}{c}0.103^{*} \\
{[0.053]}\end{array}$ & & $\begin{array}{c}0.054 \\
{[0.063]}\end{array}$ & & $\begin{array}{c}0.168 \\
{[0.131]}\end{array}$ & & $\begin{array}{c}0.210 \\
{[0.134]}\end{array}$ \\
\hline Secondary fund style & & $\begin{array}{c}-0.088 \\
{[0.094]}\end{array}$ & & $\begin{array}{c}-0.186 \\
{[0.128]}\end{array}$ & & $\begin{array}{c}0.166 \\
{[0.157]}\end{array}$ & & $\begin{array}{c}0.082 \\
{[0.369]}\end{array}$ \\
\hline Vintage Year FE & $\mathrm{Y}$ & $\mathrm{Y}$ & $\mathrm{Y}$ & $\mathrm{Y}$ & $\mathrm{Y}$ & $\mathrm{Y}$ & $\mathrm{Y}$ & $\mathrm{Y}$ \\
\hline $\mathrm{N}$ & 359 & 359 & 212 & 212 & 418 & 418 & 418 & 272 \\
\hline $\mathrm{R} 2$ & 0.1 & 0.11 & 0.1 & 0.11 & 0.15 & 0.16 & 0.15 & 0.17 \\
\hline
\end{tabular}

